\title{
THE BILL OF RIGHTS AS A TERM OF ART
}

\author{
Gerard N. Magliocca*
}

It certainly must be immaterial what mode is observed as to the order of declaring the rights of the citizens, if they are to be found in any part of the instrument which establishes the government. And hence it must be apparent that much of what has been said on this subject rests merely on verbal and nominal distinctions, which are entirely foreign from the substance of the thing. ${ }^{1}$

\section{INTRODUCTION}

The Bill of Rights is a sacred part of our Constitution, but why do we use that term to describe the first set of amendments?2 A legal claim is not stronger if the guarantee falls within the Bill of Rights as opposed to, say, the Equal Protection Clause or a part of Article I. Moreover, the Supreme Court has repeatedly declined to hold that a right in the Bill of Rights is ipso facto a fundamental right, ${ }^{3}$ and hardly anyone now thinks that Amendment III or Amendment VII carries the same weight as Amendment I. ${ }^{4}$ What, then, is the point of saying that all of these provisions are part of a bill of rights when the text ratified in 1791 does not use that phrase?5

(c) 2016 Gerard N. Magliocca. Individuals and nonprofit institutions may reproduce and distribute copies of this Article in any format at or below cost, for educational purposes, so long as each copy identifies the author, provides a citation to the Notre Dame Law Review, and includes this provision in the copyright notice.

* Samuel R. Rosen Professor, Indiana University Robert H. McKinney School of Law. Thanks to Richard Primus and to the American Bar Foundation, which hosted a workshop on this paper, for their feedback on prior drafts.

1 The Federalist No. 84, at 581 (Alexander Hamilton) (Jacob E. Cooke ed., 1961).

2 This Article uses "the first set of amendments" rather than "the first ten amendments" to describe the Bill of Rights because some Supreme Court cases define the Bill of Rights as only the first eight or the first nine amendments. See, e.g., Twining v. New Jersey, 211 U.S. 78, 98 (1908) (using the first eight); Kepner v. United States, 195 U.S. 100, 123 (1904) (using the first nine).

3 See, e.g., McDonald v. City of Chicago, 561 U.S. 742, 760-61 (2010) (stating that a right is not fundamental (and thus applicable to the states) merely because it is in the Bill of Rights); Hurtado v. California, 110 U.S. 516, 516 (1884) (holding that the grand jury requirement of the Fifth Amendment is not a fundamental right and does not apply to the states).

4 See U.S. Const. amend. III (prohibiting the quartering of troops in private homes during peacetime); $i d$. at amend. VII (guaranteeing the right to a civil jury in common law cases worth more than twenty dollars).

5 See, e.g., Samuel F. Miller, The Constitution of the United States: Three Lectures Delivered Before the University Law School of Washington, D.C. 59 (1880) 
This Article argues that the use of the "Bill of Rights" to describe the first set of constitutional amendments emerged long after the Founding as a justification for expanding federal power at home and abroad. In making that claim, I challenge two common misconceptions about the Bill of Rights. One is that the first set of amendments was known by that name from the start. ${ }^{6}$ This is not true. James Madison never said that what was ratified in 1791 was a bill of rights, ${ }^{7}$ and that label was not widely used for those provisions until after $1900 .{ }^{8}$ The second fallacy is that the Bill of Rights was a term of art designed to limit government through judicial review. ${ }^{9}$ While this is the modern understanding of the Bill of Rights, that idea did not become part of constitutional grammar until World War II. ${ }^{10}$

During the ratification debates on the Constitution, some Anti-Federalists protested that adding a bill of rights to the proposal was tantamount to throwing "a tub to the whale," by which they meant that such a text would be just a decoy that would legitimate federal power. ${ }^{11}$ In practice, this was what

("Our Constitution, unlike most modern ones, does not contain any formal declaration or bill of rights.”).

6 See, e.g., Maxwell v. Dow, 176 U.S. 581, 607 (1900) (Harlan, J., dissenting) (stating that ever since 1791 the first set of amendments was regarded as our national Bill of Rights).

7 My review of Madison's papers uncovered no such references. A few days after the first ten amendments were ratified, he wrote a newspaper column that explained: "In proportion as government is influenced by opinion, it must be so, by whatever influences opinion. This decides the question concerning a Constitutional Declaration of Rights, which requires an influence on government, by becoming a part of the public opinion." James Madison, Public Opinion, Nat'L Gazette (Dec. 19, 1791), reprinted in 14 The Papers of James Madison 170, 170 (Robert A. Rutland et al. eds., 1983) This may have been a way of calling what was just ratified a Declaration of Rights, but if so this was very oblique.

8 See Akhil Reed Amar, The Bill of Rights: Creation and Reconstruction 284-87 (1998) (explaining that the first set of constitutional amendments was rarely called a bill of rights before Reconstruction); Pauline Maier, Ratification: The People Debate The Constitution, 1787-1788, at 459-65 (2010) (making a similar point); Pauline Maier, The Strange History of the Bill of Rights (Apr. 10, 2013), http://scholarship.law.georgetown.edu/ hartlecture/30/ (presenting additional evidence for her claim); see also Robertson v. Baldwin, 165 U.S. 275, 281 (1897) (marking the first time that the Supreme Court called the first set of amendments the Bill of Rights); John W. Wertheimer, A "Switch in Time" Beyond the Nine: Historical Memory and the Constitutional Revolution of the 1930s, 53 STUd. In Law, Pol. \& Soc'y 3 (exploring the rise of the Bill of Rights in the 1930s from obscurity).

9 See, e.g., Griswold v. Connecticut, 381 U.S. 479, 484 (1965) (justifying the right of privacy on the ground that the "guarantees in the Bill of Rights have penumbras, formed by emanations from those guarantees that help give them life and substance"); W. Va. State Bd. of Educ. v. Barnette, 319 U.S. 624, 638 (1943) ("The very purpose of a Bill of Rights was to withdraw certain subjects from the vicissitudes of political controversy, to place them beyond the reach of majorities and officials and to establish them as legal principles to be applied by the courts.").

10 See infra Part V. For an overview of other functions that a bill of rights can perform, see David A. Strauss, The Role of a Bill of Rights, 59 U. CHI. L. REv. 539 (1992).

11 See, e.g., Kenneth R. Bowling, "A Tub to the Whale": The Founding Fathers and Adoption of the Federal Bill of Rights, 8 J. EARly RePublic 223 (1988) (providing an excellent overview 
calling the 1791 amendments the Bill of Rights mostly did when that label was used prior to 1945. The first move in this direction came during Reconstruction, when a few members of Congress, especially John A. Bingham, used that term of art because they wanted to overturn Barron v. Baltimore ${ }^{12}$ and extend the first set of amendments to the states. ${ }^{13}$ By calling that list the Bill of Rights, Bingham was trying to persuade his colleagues that this expansion of national power was a valid exception to states' rights. ${ }^{14}$

While Bingham did not change either the name or the scope of those amendments during his era, both aspects began to assume their modern form after the Spanish-American War. Critics of imperialism such as William Jennings Bryan argued that our democracy could not endure if we withheld the "Bill of Rights" from the Philippines. ${ }^{15}$ President William McKinley and Congress answered this challenge by extending part of the first set of amendments in what was later called the Philippine Bill of Rights. ${ }^{16}$ This watereddown version of the original was vital in easing concerns about unprecedented federal control over territories that would never be admitted as states.

The New Deal and World War II elevated the Bill of Rights to its present iconic status in an effort to increase national power still further. Liberals are fond of Franklin D. Roosevelt's "Second Bill of Rights" that sought to grant positive rights such as health care and education, ${ }^{17}$ but FDR also brandished the first Bill of Rights to deflect charges that the growth of the welfare state

of this criticism). The idea was that a ship in danger from a whale would throw a wooden tub into the water in the hopes that the whale would attack the tub instead of the ship. Id. 1232 U.S. (7 Pet.) 243 (1833).

13 See, e.g., Gerard N. Magliocca, American Founding Son: John Bingham and the Invention of the Fourteenth Amendment 114-17 (2013).

14 See Cong. Globe, 39th Cong., 1st. Sess. 1088 (1866) (statement of Rep. Bingham) ("The proposition pending before the House is simply a proposition to arm the Congress of the United States, by the consent of the people of the United States, with the power to enforce the bill of rights as it stands in the Constitution today. It 'hath that extent-no more." ); $i d$. at 1089 (rejecting the argument that he was "impairing State rights").

15 See, e.g., Mr. Bryan's Speech of Acceptance, N.Y. Times, Aug. 9, 1900 [hereinafter Bryan's Speech] (reproducing Bryan's acceptance speech for the Democratic nomination, in which he attacked those who claimed "the right to treat millions of people as mere 'possessions' and deal with them unrestrained by the Constitution or the Bill of Rights"); 1 NATIONAL Party Platforms 112 (Donald Bruce Johnson, ed. 1978) (giving the text of the 1900 Democratic Platform, which stated that "no nation can long endure half republic and half empire, and we warn the American people that imperialism abroad will lead quickly and inevitably to despotism at home”).

16 See Philippine Organic Act, Pub. L. No. 57-235, 32 Stat. 691, 692-93 (1902) (listing these privileges); see also Dowdell v. United States, 221 U.S. 325, 329 (1911) (naming "the so-called Philippine Bill of Rights, which is substantially taken from the Bill of Rights of the Federal Constitution" (citing Kepner v. United States, 195 U.S. 100 (1904)); Kepner, 195 U.S. at 123 (describing these protections as "the familiar language of the Bill of Rights").

17 See Franklin D. Roosevelt, Message on the State of the Union (Jan. 11, 1944), in 1944-45 Public Papers and Addresses of Frankiln D. Roosevelt 40-42 (Samuel I. Rosenman ed., 1950) [hereinafter Roosevelt Papers] (discussing the Second Bill of Rights); Cass R. Sunstein, The Second Bill of Rights: FDR's Unfinished Revolution and Why We Need It More Than Ever (2004). 
threatened individual liberty. The attack was false, the President explained in one of his early Fireside Chats, because the gold standard of liberty was the Bill of Rights, and those freedoms were not being infringed. ${ }^{18}$

Roosevelt also stressed the Bill of Rights to distinguish the United States from the Third Reich. ${ }^{19}$ Initially this comparison was used to suggest that federal inaction on economic reform could lead to a domestic tyranny that would destroy the Bill of Rights. ${ }^{20}$ Later on the President used the contrast to argue that Nazism presented a threat that required bold federal action (such as military conscription in peacetime). ${ }^{21}$ Indeed, a week after Hitler declared war on America, FDR transformed the Bill of Rights into a patriotic emblem in an address that attacked the Führer by name and justified the war effort. $^{22}$ In this instance, as in the aftermath of the Spanish-American War,

18 See Franklin D. Roosevelt, Fireside Chat (Jun. 28, 1934), in FDR's Fireside Chats 49 (Russell D. Bulhite \& David W. Levy eds., 1992) [hereinafter Fireside Chat] ("Turn to the Bill of Rights of the Constitution, which I have solemnly sworn to maintain and under which your freedom rests secure. Read each provision of that Bill of Rights and ask yourself whether you personally have suffered the impairment of a single jot of these great assurances."); see also Franklin D. Roosevelt, Annual Message to the Congress (Jan. 4, 1939), in 1939 Roosevelt Papers, supra note 17, at 6 (1941) (boasting that the New Deal's reforms were made without curbing "freedom of speech, freedom of the press or the rest of the Bill of Rights").

19 See Franklin D. Roosevelt, Address on the Occasion of the One Hundred and Fiftieth Anniversary of the Congress (Mar. 4, 1939), in 1939 Roosevelt PAPERs, supra note 17, at 152 (1941) [hereinafter 150th Anniversary of Congress Address] ("In that Bill of Rights lies another vast chasm between our representative democracy and those reversions to personal rule which have characterized these recent years.").

20 See Franklin D. Roosevelt, Address on Constitution Day (Sept. 17, 1937), in 1937 Roosevelt PAPERs, supra note 17, at 366-67 (1941) [hereinafter Constitution Day Address] ("Nothing would so surely destroy the substance of what the Bill of Rights protects than its perversion to prevent social progress . . . . Desperate people in other lands surrendered their liberties when freedom came merely to mean humiliation and starvation.").

21 See Franklin D. Roosevelt, Acceptance Speech to the 1940 Democratic National Convention (July 19, 1940), in 1940 Roosevelt PAPERs, supra note 17, at 301 (1941) [hereinafter Acceptance Speech] ("It is our credo-unshakable to the end-that we must live under the liberties that were first heralded by Magna Carta and placed into glorious operation through the Declaration of Independence; the Constitution of the United States and the Bill of Rights . . . . If our Government should pass to other hands next Januaryuntried hands, inexperienced hands-we can merely hope and pray that they will not substitute appeasement and compromise with those who seek to destroy all democracies everywhere, including here."); $c f$. Franklin D. Roosevelt, The Annual Message to the Congress (Jan. 6, 1941), in 1940 Roosevelt PAPers, supra note 17, at 672 (1941) (discussing the threat of the dictators and outlining the President's Four Freedoms-freedom of speech, freedom of religion, freedom from want, and freedom from fear).

22 See Franklin D. Roosevelt, Radio Address Commemorating the 150th Anniversary of the Ratification of the Bill of Rights (Dec. 15, 1941), in 1941 Roosevelt PAPERs, supra note 17, at 555 (declaring that Hitler sought "the overthrow, throughout the earth, of the great revolution of human liberty of which our American Bill of Rights is the mother charter"); see also Franklin D. Roosevelt, Bill of Rights Day Proclamation (Nov. 27, 1941), in 1941 RoOsevelt PAPers, supra note 17, at 497-99. 
the influence of foreign affairs on our constitutional law comes into focus in a way that most interpretive theories do not fully capture. ${ }^{23}$

Part I explores the original understanding of a bill of rights and looks at why the first set of amendments was not considered one at the Founding. Part II discusses how the term was first advanced to legitimate the growth of federal power through incorporation. Part III examines how that rhetoric expanded after the Spanish-American War to support imperialism. Part IV assesses how the Bill of Rights was wielded by President Roosevelt to justify the welfare state and meet the challenge presented by Nazi Germany. Part V concludes by tracing the evolution of the Bill of Rights into its present role as a tool for supporting judicial review.

\section{The Original Understanding}

This Part reviews the original understanding of a bill of rights. Given the importance of this phrase in American constitutionalism, it is rather surprising that so little has been written on that subject. We must explain why the first set of amendments was rarely called a bill of rights in the eighteenth and nineteenth centuries to grasp why and how that parlance changed. Part of the answer is that the term was reserved (except by Alexander Hamilton) for a text that appeared at the front of a constitution and made sweeping claims about natural rights and popular sovereignty, neither of which were attributes of the first set of amendments. Most important of all, no purpose was served by using "The Bill of Rights" to describe what was ratified in 1791 as there was for the Declaration of Rights by the Continental Congress, for the state bills of rights written during the Revolution, or for most of the AntiFederalists seeking to defeat the Constitution.

\section{A. A Puzzling Omission}

Let us begin with a fact that is hard to believe: there is little evidence that the first set of amendments was called a bill of rights or a declaration of rights (let alone "The Bill of Rights") when Congress proposed that text in 1789 or when it was ratified in $1791 .{ }^{24}$ Instead, almost everyone referred to the "amendments to the Constitution." 25 Nobody in the First Congress

23 There are excellent case studies on the influence of foreign policy on domestic law, see, e.g., Mary L. Dudziak, Cold War Civil Rights: Race and the Image of American Democracy (paperback reissue with a new preface 2011), but grand constitutional theorists have not addressed the relevance of international affairs in a systematic way.

24 See Maier, supra note 8, at 459-60 ("Between September 1789 and early 1792, nobody seems to have referred to either the twelve amendments proposed by Congress in September 1789 or the ten that were ratified by the end of 1791 as a 'bill of rights." ). One significant caveat is that the Senate did not keep records of its debates during the First Congress. See 1 Annals of Cong. (1789) (Joseph Gales ed., 1834). As a result, there is a chance that senators referred to the proposed amendments as a bill of rights, but we will never know.

25 See 1 The Debates in the Several State Conventions on The Adoption of the Federal Constitution as Recommended by the General Convention at Philadelphia in 
described what was sent to the states as a bill of rights. ${ }^{26}$ Nobody in the ratifying state legislatures used that term for the amendments, ${ }^{27}$ nor did President Washington. ${ }^{28}$ I do not claim that those magic words were never used to describe the first set of amendments, as Jefferson did write one letter in 1792 that stated: " $[\mathrm{M}] \mathrm{y}$ objection to the Constitution was, that it wanted a bill of rights securing freedom of religion, freedom of the press, freedom from standing armies, [and] trial by jury .... The sense of America has approved my objection and added the bill of rights." ${ }^{29}$ But this is the only such statement that I can find, which means that I am sure that this was not common usage then. ${ }^{30}$

The absence of references to the Bill of Rights in the 1790s is telling because the issue of whether the Constitution should have a bill of rights was hotly debated during the ratification debates on the original text. ${ }^{31}$ If the issue had not been raised at that time, then one might not attribute much significance to the fact that people did not call the first set of amendments a bill of rights. But we know that the Anti-Federalists protested at length about

1787, at 375 (Jonathan Elliot ed., 2d ed. 1836) [hereinafter The Debates] (quoting Congress's resolution attached to the proposed first set of amendments resolving that "the following articles be proposed to the legislatures of the several states, as amendments to the constitution of the United States"); MAIER, supra note 8, at 460 (quoting Secretary of State Jefferson's proclamation announcing the ratification of "certain articles in addition and amendment of the Constitution of the United States").

26 This assertion is based on a review of the debates in the House of Representatives during the First Congress, which can be found in 1 Annals of Cong. (1789) (Joseph Gales ed., 1834).

27 No single cite can support this proposition, but a search of available materials on the state ratification debates turned up no instances in which the first set of amendments was called a bill of rights. See, e.g., The Debates, supra note 25 (no mention of a "bill of rights" in state ratification debates material).

28 See, e.g., 1 A Compilation of the Messages and Papers of the Presidents 63 (James D. Richardson ed., 1897) [hereinafter Messages] (quoting President Washington's acknowledgement that the Maryland legislature had ratified "certain articles in addition to and amendment of the Constitution of the United States of America, proposed by Congress to the legislatures of the several States").

29 Letter from Thomas Jefferson to George Washington, Sept. 9, 1792, in 3 The WRITings of Thomas Jefferson 459, 463 (H.A. Washington ed., 1854). John Bingham later paraphrased this as: "Jefferson well said of the first eight articles of amendments to the Constitution of the United States, they constitute the American Bill of Rights." Cong. GLobe, 42nd Cong., 1st Sess. 84 app. (1871) (statement of Rep. Bingham). This is not quite right, as Jefferson never singled out the first eight amendments (as opposed to the first ten), but Bingham did capture the spirit of Jefferson's statement.

30 See MaIER, supra note 8, at 461 (stating that newspapers at the time did not call the first set of amendments a bill of rights). Jefferson never again referred to this Bill of Rights, even during the crisis over the Alien and Sedition Acts later in the 1790s.

31 See, e.g., 3 Joseph Story, Commentaries on the Constitution of the United STATEs 713 (1833) (“[M]any objections were taken to the constitution, not only on account of its actual provisions, but also on account of its deficiencies and omissions. Among the latter, none were proclaimed with more zeal, and pressed with more effect, than the want of a bill of rights." (footnote omitted)). 
the need for a bill of rights, and New York, North Carolina, and Virginia proposed the addition of a bill of rights at the conclusion of their ratifying conventions. ${ }^{32}$ Why then did most people not consider what was ratified a bill of rights?

One place to look for an answer is in the state bills of rights of that era. Six states had a self-described bill or declaration of rights in 1791 (Maryland, Massachusetts, New Hampshire, North Carolina, Vermont, and Virginia). ${ }^{33}$ One trait that all but one of these bills of rights shared was that they came right before or after a preamble. ${ }^{34}$ The first set of amendments, by contrast, appears at the end of the Constitution, mainly because Roger Sherman argued that what was proposed in 1787 should be kept apart from any future changes. ${ }^{35}$ The other characteristic that stands out in the state bills of rights is that they made abstract claims about government. ${ }^{36}$ For example, Virginia's Declaration of Rights stated:

[A]ll men are by nature equally free and independent, and have certain inherent rights, of which, when they enter into a state of society, they cannot, by any compact, deprive or divest their posterity; namely, the enjoyment of life and liberty, with the means of acquiring and possessing property, and pursuing and obtaining happiness and safety. ${ }^{37}$

32 See 3 The Debates, supra note 25, at 657-61 (reproducing Virginia's proposed "declaration or bill of rights"); 4 The DeBATEs, supra note 25, at 242-47 (reproducing North Carolina's proposed "Declaration of Rights"); MAIER, supra note 8, at 397 (explaining that New York's ratification of the Constitution opened with a declaration of rights).

33 See Md. Const. of 1776; Mass. Const. of 1780; N.H. Const. of 1784; N.C. Const. of 1776; Vt. Const. of 1786; VA. Declaration of Rights of 1776.

34 The Virginia Declaration of Rights is the exception, as it was issued as a freestanding text, see Jack N. Rakove, Original Meanings: Politics and Ideas in the Making of the Constitution 306 (1996), like the English Declaration of Rights of 1689, see infra Section I.B.

35 See Maier, supra note 8, at 453. The amendments proposed by the New York, $i d$. at 397, North Carolina, 4 The Debates, supra note 25, at 242, and Virginia, 3 The Debates, supra note 25, at 657 , ratifying conventions each opened with a bill of rights. When George Mason proposed a bill of rights near the end of the Constitutional Convention, he said he "wished the plan had been prefaced with a Bill of Rights." 2 The Records of THE Federal Convention of 1787, at 587 (Max Farrand ed., 1937) (emphasis added).

36 Cf. Amar, supra note 8, at 131-32 (Amar discusses Patrick Henry's comment at the Virginia 1788 ratifying convention, in which he said: "[T] here are certain maxims by which every wise and enlightened people will regulate their conduct . . . our . . . bill of rights contains those admirable maxims.").

37 Va. Declaration of Rights of 1776, art. I; see id. at art. III ("[G]overnment is, or ought to be, instituted for the common benefit, protection, and security, of the people, nation, or community; of all the various modes and forms of government that is best, which is capable of producing the greatest degree of happiness and safety, and is most effectually secured against the danger of mal-administration; and that whenever any government shall be found inadequate or contrary to these purposes, a majority of the community hath an indubitable, unalienable, and indefeasible right, to reform, alter, or abolish it, in such manner as shall be judged most conducive to the publick weal."). 
This statement and others of a similar bent in the Virginia Declaration were widely admired and copied, both by Jefferson in drafting the Declaration of Independence and by the other state bills of rights. ${ }^{38}$ The first set of amendments, of course, does not make these sorts of claims. ${ }^{39}$ "A well regulated Militia, being necessary to the security of a free State" is the only exception, ${ }^{40}$ but the rest of what we consider the Bill of Rights consists of specific rules, broad standards, or rules of construction.

The observation that the first set of amendments did not look like the state bills of rights at the time does not, of course, prove that those distinctions were meaningful, but Alexander Hamilton's essay defending the Constitution against the charge that the proposal did not include a bill of rights suggests that these differences did matter. Federalist No. 84 presents Hamilton's famous argument that a bill of rights was dangerous because enumerating liberties implied that the new government had powers that were not enumerated. ${ }^{41}$ But his essay also criticized the view that a bill of rights must

38 See Vt. Const. of 1786, art. I (“[A]ll men are born equally free and independent, and have certain natural, inherent, and unalienable rights; amongst which are, the enjoying and defending life and liberty; acquiring, possessing, and protecting property; and pursuing and obtaining happiness and safety."); see also MD. Const. of 1776, art. I ("[A]ll government of right originates from the people, is founded in compact only, and instituted solely for the good of the whole."); MAss. Const. of 1780, art. V ("All power residing originally in the people, and being derived from them, the several magistrates and officers of government, vested with authority, whether legislative, executive, or judicial, are their substitutes and agents, and are at all times accountable to them."); N.H. Const. of 1784, art. III ("When men enter into a state of society, they surrender up some of their natural rights to that society, in order to insure the protection of others; and, without such an equivalent, the surrender is void.”); N.C. CONST. of 1776, art. I (“[A]ll political Power is vested in, and derived from, the People ...."). The influence of the Virginia Declaration on Jefferson's draft was substantial. See, e.g., Walter Isaacson, Benjamin Franklin: An AMERICAN Life 311 (2003) (stating that his draft of the Declaration of Independence borrowed from the Virginia Declaration "in a manner that today might subject him to questions of plagiarism but back then was considered not only proper but learned").

39 The amendments proposed by the state ratifying conventions did include these kinds of maxims. See, e.g., 3 The Debates, supra note 25, at 657 (giving Virginia's proposal, which included: "[N]o man or set of men are entitled to separate or exclusive public emoluments or privileges from the community, but in consideration of public services, which not being descendible, neither ought the offices of magistrate, legislator, or judge, or any other public office, to be hereditary."); 4 The Debates, supra note 25, at 243 (reproducing North Carolina's proposal that included: "[G]overnment ought to be instituted for the common benefit, protection, and security, of the people; and that the doctrine of nonresistance against arbitrary power and oppression is absurd, slavish, and destructive to the good and happiness of mankind.").

40 U.S. Const. amend II; see District of Columbia v. Heller, 554 U.S. 570, 595-98 (2008) (discussing this portion of the Second Amendment).

41 See The Federalist No. 84, at 579 (Alexander Hamilton) (Jacob E. Cooke ed., 1961) ("Why for instance, should it be said, that the liberty of the press shall not be restrained, when no power is given by which restrictions may be imposed? I will not contend that such a provision would confer a regulating power; but it is evident that it would furnish, to men disposed to usurp, a plausible pretence for claiming that power.”) 
come near the start of a constitution. Hamilton said "the [proposed] constitution is itself in every rational sense, and to every useful purpose, A BILL OF RIGHTS." ${ }^{22}$ The text accomplished what he saw as the two important objectives of a bill of rights, which were "to declare and specify the political privileges of the citizens in the structure and administration of the government" and "to define certain immunities and modes of proceeding, which are relative to personal and private concerns." 43 "It certainly must be immaterial," Hamilton stated, "what mode is observed as to the order of declaring the rights of the citizens, if they are to be found in any part of the instrument which establishes the government." ${ }^{4} \mathrm{He}$ also ridiculed the practice of putting abstract ideas about government into a bill of rights. Federalist No. 84 argued that the Preamble was "a better recognition of popular rights than volumes of those aphorisms which make the principal figure in several of our state bills of rights, and which would sound much better in a treatise of ethics than in a constitution of government." ${ }^{5}$ In dismissing the view that a bill of rights needed to have "those aphorisms," Hamilton was implying that this was the expectation.

Likewise, when Madison proposed the first set of amendments, he indicated that these two formal aspects of state bills of rights were relevant. ${ }^{46} \mathrm{He}$ described the first part of his package as follows:

That there [should] be prefixed to the constitution a declaration, that all power is originally vested in, and consequently derived from, the people.

That Government is instituted and ought to be exercised for the benefit of the people; which consists in the enjoyment of life and liberty, with the right of acquiring and using property, and generally of pursuing and obtaining happiness and safety.

That the people have an indubitable, unalienable, and indefeasible right to reform or change their Government, whenever it be found adverse or inadequate to the purposes of its institution. ${ }^{47}$

After reading his other amendments, including the draft of what was ultimately ratified by the states, Madison said that the "first of these amendments relates to what may be called a bill of rights." 48 In other words, only the part just quoted was in his view a "bill of rights." 49

42 Id. at 581; see id. at 576-78 (discussing the provisions in the 1787 text that protected fundamental rights).

$43 \quad I d$. at 581.

44 Id.

$45 \quad I d$. at 579.

46 See 1 Annals of Cong. 448-59 (1789) (Joseph Gales ed., 1834) (statement of Rep. Madison).

47 Id. at 451.

$48 \quad I d$. at 453.

49 Madison then discussed the case for and against a bill of rights, see id. at 453-57, but without the prefix what he proposed was not a bill of rights, as indicated by his unwillingness to use that term for the first set of amendments after ratification. See supra text accompanying note 7 . 
Madison's proposed bill of rights (rather than the one now attributed to him) copied the state bills of rights by coming at the start of the constitution and by making general statements about natural rights and popular sovereignty. His language drew on the Virginia Declaration of Rights, and like Hamilton he used the term "prefix" in connection with the prevailing understanding of a bill of rights. In committee, Madison's prefix was whittled down to just one phrase that preceded the Preamble: "Government being intended for the benefit of the people, and the rightful establishment thereof being derived from their authority alone." 50 The House of Representatives later struck that part of Madison's draft and turned the first set of amendments into a "suffix" with virtually no rhetorical flourishes. ${ }^{51}$ In so doing, the First Congress kept the Constitution free of a bill of rights as many understood that term in 1791.52

\section{B. The Very Purpose of a Bill of Rights}

Formalities aside, the first set of amendments was not called a bill of rights after the Founding because there was no reason to do so. The formal part of my explanation is incomplete because the form of a bill of rights changed substantially in the $1770 \mathrm{~s}$, and therefore it is hard to say that the meaning of that term was fixed. The English Bill of Rights of 1689, for example, was framed as an indictment of King James II in support of the Glorious Revolution. ${ }^{53}$ Though this model was followed by the Declaration of Independence, state bills of rights avoided these accusations. Likewise, we pay almost no attention to the formal traits that Hamilton and Madison noted in their discussion of bills of rights. ${ }^{54}$ Why would they have cared so much about them when their predecessors and their remote ancestors cared so little?

A more pragmatic explanation is that Americans identified texts as bills of rights to achieve a crucial political objective. When the First Continental Congress issued its "Declaration of Rights and Grievances" in 1774, that term was chosen to add legitimacy to its protest about British policy by invoking

50 Leonard W. Levy, Origins of the Bill of Rights 284 (1999).

51 Richard Labunski, James Madison and the Struggle for the Bill of Rights 232 (2006).

52 Indeed, in September 1792 an anonymous pamphlet denied that we had a national bill of rights: "As long as the States of America continue united under the present form of government, the PEOPLE will have to lament the want of a Bill of Rights, which would clearly and unequivocally dictate to the Legislature its duty, and to the People their rights." George Logan, Five Letters, Addressed to the Yeomanry of the United States: Containing Some Observations on the Dangerous Scheme of Governor Duer and Mr. Secretary Hamilton, to Establish National Manufactories 3 (1792).

53 See An Act Declaring the Rights and Liberties of the Subject and Settling the Succession of the Crown 1689, 1 W. \& M. c. 2 (Eng.).

54 In fairness, state bills of rights retain these qualities (in other words, they almost always come at the start of their constitutions and include statements of first principles). Few people, though, think about these texts now, especially as compared to the national bill of rights that lacks these attributes. 
the precedent of the English Declaration of Rights of 1689, which was later enacted by Parliament as the Bill of Rights. ${ }^{55}$ When the states declared independence from the Crown, putting a declaration or bill of rights in their constitutions was a way of justifying secession by linking their revolutionary acts to the Glorious Revolution. ${ }^{56}$ And when Anti-Federalists attacked the Constitution for not having a bill of rights, using that phrase was an effective way of crystallizing fears that the federal government would be too powerful. 57

Once independence was achieved and the Constitution was ratified, there was no overarching rationale for saying that the 1791 amendments constituted a bill of rights. Such a rationale could have been found in subsequent constitutional controversies over the Alien and Sedition Acts, slavery, or other topics. ${ }^{58}$ But that did not happen until reformers became interested in expanding the first set of amendments to include the actions of state governments.

\section{INCORPORATION}

This Part shows how the "Bill of Rights" first emerged through the efforts of those who advocated the application of the initial set of amendments to the states. Faced with objections grounded in states' rights, supporters of extending those provisions attempted to raise their status by calling them a bill of rights. While this rhetoric did not bear fruit until the midtwentieth century, those efforts-especially the speeches of John Bingham during the Thirty-Ninth Congress-laid the foundation for the subsequent canonization of the Bill of Rights and the concomitant expansion of federal power.

55 See 1 Journals of the Continental Congress 1774-1789, at 63-73 (Worthington Chauncey Ford ed., 1904) (discussed on Oct. 14, 1774). The English Declaration of Rights was issued by an irregular Parliament sitting without a King, and after William III was crowned the Declaration was reenacted as the Bill of Rights. For an analysis of both texts, see Lois G. Schwoerer, The Declaration of Rights, 1689 (1981).

56 Cf. Bernard Bailyn, The Ideological Origins of the American Revolution 202-04 (1967) (summarizing the importance of the 1689 precedents on the Founders).

57 Granted, some saw the phrase as nothing more than a cover to the Constitution's enhancement of federal power, see supra text accompanying note 11 , but that was not the dominant view.

58 As my forthcoming book explains, until the 1870s there were almost as many uses of "Bill of Rights" to refer to the Declaration of Independence as there were for the first set of amendments, thus there was simply no agreement on this vernacular. See, e.g., Charles Sumner, A Letter from Senator Sumner: His Advice to the Colored National Convention, N.Y. HerALD TRIB., Apr. 15, 1872, at 5 (reproducing a letter from Senator Charles Sumner to an African-American gathering describing the Declaration of Independence as "in the nature of a bill of rights preceding the Constitution”). 


\section{A. Barron v. Baltimore}

Until the 1830 s, there was almost no discussion on the first set of amendments, but in 1833 the Supreme Court decided Barron and revealed that the consensus on a bill of rights had not changed much from Hamilton and Madison's day. ${ }^{59}$ Barron involved a claim that the Takings Clause applied to the states, but Chief Justice Marshall held for a unanimous Court that the first set of amendments applied only to the federal government. ${ }^{60}$ A modern reader may be surprised to learn that the Chief Justice's opinion never called those amendments a bill of rights. He said only that:

In almost every convention by which the constitution was adopted, amendments to guard against the abuse of power were recommended. . . .

In compliance with a sentiment thus generally expressed, to quiet fears thus extensively entertained, amendments were proposed by the required majority in congress, and adopted by the states. ${ }^{61}$

Barron went on to say that Article I, Section 9 "enumerated, in the nature of a bill of rights, the limitations intended to be imposed on the powers of the general government."62 In other words, the leading antebellum case on the Bill of Rights called another part of the Constitution something like a bill of rights. ${ }^{63}$

Why did Barron say that Article I, Section 9 was in the nature of a bill of rights rather than a bill of rights? One possible answer is that the Court, like most of the framers, believed that a constitutional bill of rights was limited to a list that came near the start of a text and made abstract statements about natural rights and popular rule. ${ }^{64}$ Since no section of the Constitution had

59 The only significant reference that I can find to what we call the Bill of Rights between 1792 and 1833 came in Aaron Burr's treason trial, where his lawyer, Edmund Randolph, told the Court that admitting a certain affidavit would violate the Confrontation Clause. See 1 The Trial of Col. Aaron Burr on an Indictment for Treason 49 (T. Carpenter ed., 1807) ("By the Bill of Rights, a man has a right to be confronted with the witnesses against him.").

60 See Barron v. Baltimore, 32 U.S. (7 Pet.) 243, 250-51 (1833).

61 Id. at 250; see Ex Parte Burford, 7 U.S. (3 Cranch) 448, 451 (1806) (separating "the bill of rights, of Virginia" and the "amendments to the $[\mathrm{C}]$ onstitution of the United States").

62 Barron, 32 U.S. (7 Pet.) at 248; see Cummings v. Missouri, 71 U.S. (4 Wall.) 277, 325 (1867) (discussing "the second clause of what Mr. Chief Justice Marshall terms a bill of rights for the people of each State-the clause which inhibits the passage of an ex post facto law"); Piqua Branch of the State Bank v. Knoop, 57 U.S. (16 How.) 369, 392 (1854) (describing Article I, Section 10 as "in the emphatic language of Chief Justice Marshall, a bill of rights to the people of the States").

63 Although Justice Joseph Story joined the Court's opinion in Barron, his constitutional treatise called the Second Amendment part of "our national bill of rights." See 3 STORY, supra note 31, at 747. Justice Story also described the Double Jeopardy Clause as part of "a bill of rights" in a circuit opinion. United States v. Gibert, 25 F. Cas. 1287, 1297 (C.C.D. Mass. 1834) (No. 15,204).

64 Another possibility is that the Court was just unwilling to call anything a bill of rights unless that designation was actually in the text. 
these traits, the most one could say about some other part of the text was that it was "sort of" a bill of rights, meaning that the formalities were absent while the substance was present. A way of expressing this idea was through the "in the nature of" language, and this was how almost every case discussed a bill of rights in connection with the first set of amendments (on the rare occasions when they did) until the 1890s. ${ }^{65}$ In effect, this was the position that Hamilton advanced in Federalist No. 84, which was that a constitution could have "provisions in favour of particular privileges and rights, which in substance amount to" a bill of rights without having that title. ${ }^{66}$ The surprising fact, though, is that portions of Article I, not the first eight or ten amendments, were deemed the closest thing to a bill of rights in the Constitution. ${ }^{67}$

The first Supreme Court reference to what we call the Bill of Rights was in 1840 by an attorney who mentioned "the amendments to the Constitution of the United States, commonly called the bill of rights." ${ }^{8}$ At first blush, this quote supports the idea that the 1791 amendments were widely viewed as a bill of rights by then. Upon closer inspection, though, an ulterior motive emerges. Counsel was trying (unsuccessfully) to persuade the Court that Barron's dicta was too broad and that the Due Process Clause of the Fifth Amendment should apply to the states. ${ }^{69}$ The full statement reads:

I am aware that it has been decided by this Court, in the case of Barron vs.

The City of Baltimore, that the amendments to the Constitution of the United

States, commonly called the bill of rights, were simply limitations of the pow-

ers of the general government, and had no effect upon the state govern-

65 See supra note 63 (noting Justice Story's circuit opinion in Gibert, which is the only exception); see also Mattox v. United States, 156 U.S. 237, 243 (1895) (calling the first set of amendments "provisions in the nature of a Bill of Rights"); Monongahela Navigation Co. v. United States, 148 U.S. 312, 324 (1893) ("The first ten amendments to the Constitution, adopted as they were soon after the adoption of the Constitution, are in the nature of a bill of rights ...."); United States v. Rhodes, 27 F. Cas. 785, 790 (C.C.D. Ky. 1866) (No. 16,151) ("The first ten amendments to the constitution, which are in the nature of a bill of rights, apply only to the national government."); Jones v. Robbins, 74 Mass. (8 Gray) 329, 340 (1857) (declaring the first set of amendments "in the nature of a bill of rights"); Тімотну Farrar, Manual of the Constitution of the United States of America $§ 437$, at 392 (1867) (using the same phrase); see also Letter from General Mason to Colonel Lyon (Nov. 17, 1798), in 1 Scourge of Aristocracy \& Repository of Pol. Truths 181, 183 (1798) (stating that the first set of amendments included "provisions equivalent to a bill of rights on the subjects of religious freedom, the trial by jury, the liberty of speech, and of the press"); Luther Martin, For the Federal Gazette, No. V, Fed. Gazette \& Balt. Daily AdverTISER, Mar. 19, 1799 (stating that the First Congress "took up the subject of amendments, in the nature of a bill of rights"). I thank Saul Cornell for drawing my attention to the Martin and Mason letters.

66 The Federalist No. 84, at 575 (Alexander Hamilton) (Jacob E. Cooke ed., 1961). .

67 See, e.g., Fletcher v. Peck, 10 U.S. (6 Cranch) 87, 138 (1810) (describing Article I, Section 10 as "what may be deemed a bill of rights for the people of each state").

68 Holmes v. Jennison, 39 U.S. (14 Pet.) 540, 555 (1840) (oral argument of C.P. Van Ness).

69 See id. One of the issues was that Vermont was seeking to extradite a fugitive to Canada in the absence of a state statute authorizing such a transfer. See id. at 545, 555. 
ments. But as the decision is a recent one, and stands alone, I trust the Court will attend to me while I submit a few remarks upon a question so important and interesting. ${ }^{70}$

There is no evidence that Americans commonly described the first set of amendments as the Bill of Rights in 1840, but the deeper point is that counsel probably chose the term because he thought that would increase the chance that the Justices would extend the scope of the Due Process Clause. ${ }^{71}$ A powerful reply to the argument that the states should have exclusive jurisdiction over the topics covered by the first set of amendments is to say, as Justice Hugo Black once did, that he "never believed that under the guise of federalism the States should be able to experiment with the protections afforded our citizens through the Bill of Rights."72 Put another way, the Bill of Rights can trump states' rights in constitutional argument, but that presupposes that the 1791 amendments are the Bill of Rights.

\section{B. Reconstruction}

The Thirty-Ninth Congress that proposed the Fourteenth Amendment saw a few more statements linking the first set of amendments to a bill of rights in support of incorporation. Jacob Howard was the floor manager of the Fourteenth Amendment in the Senate, ${ }^{73}$ and he said that the first eight amendments stand "as a bill of rights in the Constitution" and that Section 1 made these rights applicable to the states. ${ }^{74}$ Representative Robert Hale said in the House debate that the "amendments to the Constitution, numbered from one to ten" were "the bill of rights." 75 James Wilson of Iowa chimed in that the Due Process Clause of the Fifth Amendment was "in the bill of rights," 76 and Congressman William Lawrence said that the clause was in "[t] he bill of rights to the national Constitution."77

$70 \quad I d$. at 555 (citation omitted). Counsel then argued that Barron erred by treating everything in the first set of amendments alike and said that the Due Process Clause should be extended to the states even if other provisions should not be. See id. at 555-57.

71 In the Founding era, using the bill of rights was a way of basking in the glow of the English Bill of Rights, but by 1840 the state bills of rights were the more relevant source of legitimacy.

72 Duncan v. Louisiana, 391 U.S. 145, 170 (1968) (Black, J., concurring).

73 William E. Nelson, The Fourteenth Amendment: From Political Principle to Judicial Doctrine 117 (1988).

74 Cong. Globe, 39th Cong., 1st Sess. 2766 (1866) (statement of Sen. Howard). Reconstruction marked the first appearance of the assertion that the first eight amendments, rather than the first ten, constituted the Bill of Rights. See supra text accompanying note 2. When the Bill of Rights is understood as an instrument to increase national authority, the exclusion of the Tenth Amendment from that list makes sense. In fairness, though, not everyone in the Thirty-Ninth Congress took the view that the Bill of Rights included only the first eight amendments, and the omission of the Ninth Amendment is not as easy to explain.

75 Cong. Globe, 39th Cong., 1st Sess. 1064 (1866) (statement of Rep. Hale).

$76 I d$. at 1294 (statement of Rep. Wilson).

77 Id. at 1833 (statement of Rep. Lawrence). 


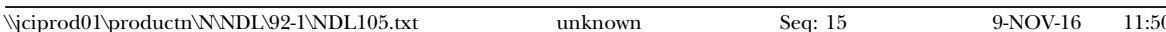

2016]

John Bingham was the most important person who called the first set of amendments the Bill of Rights, as he drafted Section 1 of the Fourteenth Amendment and argued that those clauses should apply to the actions of state governments. ${ }^{78}$ In 1862 Bingham told the House of Representatives that the Fifth Amendment was a section of the "bill of rights," 79 and in 1866 he used that term frequently, at one point stating that the Fourteenth Amendment was a remedy for the want of power "to enforce in the United States courts the bill of rights under the articles of amendment to the Constitution." 80 Indeed, one of Bingham's speeches was issued as a pamphlet entitled One Country, One Constitution, and One People: Speech of Hon. John A. Bingham of Ohio, in the House of Representatives, February 28, 1866, In Support of the Proposed Amendment to Enforce the Bill of Rights. ${ }^{81}$

Bingham and his allies were not using "bill of rights" in a Madisonian sense. They did not care about where the first set of amendments was located in the text or if the list was prefaced by something John Locke might have written. Instead, they thought that what the 1791 amendments protected was fundamental in light of the contest over slavery and used the phrase for the functional purpose of convincing their colleagues that the balance of federalism should be reset. ${ }^{82}$ Bingham was a canny politician, and he contended that the states were always morally obligated to respect these amendments, therefore extending the Bill of Rights to the States would not "take away from any State any right that belongs to it, or from any citizen of any State any right that belongs to him under that Constitution." 83 Not surprisingly, critics of the Fourteenth Amendment rejected the substance of incorporation and Bingham's rhetoric about the Bill of Rights, sticking with the traditional description of the initial set of amendments as "limitations upon the power of Congress" or the "clauses of the Constitution." 84

78 See, e.g., Adamson v. California, 332 U.S. 46, 73-74 (1947) (Black, J., dissenting) ("Congressman Bingham may, without extravagance, be called the Madison of the first section of the Fourteenth Amendment.").

79 Cong. Globe, 37th Cong., 2d Sess. 1638 (1862) (statement of Rep. Bingham).

80 Cong. Globe, 39th Cong., 1st Sess. 1089 (1866) (statement of Rep. Bingham); see AmAR, supra note 8, at 286 (noting that Bingham invoked the Bill of Rights a dozen times in a single day in Congress).

81 Magliocca, supra note 13, at 115.

82 Akhil Reed Amar, The Bill of Rights and the Fourteenth Amendment, 101 YALE L.J. 1193, 1223-35 (1992).

83 Cong. Globe, 39th Cong., 1st Sess. 1088 (1866) (statement of Rep. Bingham); see $i d$. at 1034 (stating that these "great provisions of the Constitution, this immortal bill of rights embodied in the Constitution, rested for its execution and enforcement hitherto upon the fidelity of the States"). For a detailed look at the ups and downs in Bingham's political career, see Magliocca, supra note 13.

84 AмAR, supra note 8, at 286-87 (footnotes omitted). 


\section{Back to the Supreme Court}

Like much of Reconstruction, the redefinition of the Bill of Rights fizzled during the 1870s and 1880s. ${ }^{85}$ When the Court first interpreted the Fourteenth Amendment in the Slaughterhouse Cases, the majority opinion supplied this background: "Twelve articles of amendment were added to the Federal Constitution soon after the original organization of the government under it in 1789." 86 There was no discussion of the Bill of Rights. ${ }^{87}$ Three years later, the Court said "one of the objections most seriously urged against the new constitution by those who opposed its ratification by the States [was] that it contained no formal Bill of Rights." 88 "[F] eeling on this subject," the Court continued, "led to the adoption of the first ten amendments to that instrument at one time, shortly after the government was organized." 89 Once again, though, the Court did not call them the Bill of Rights. And when a lawyer told the Justices in 1887 that the first set of amendments comprised a "Declaration of Rights" that should extend to the states, the Court replied (in an opinion by Chief Justice Waite) that "the first ten Articles of Amendment were not intended to limit the powers of the state governments." 90

In 1900 the Court finally addressed the claim that the Privileges and Immunities Clause of the Fourteenth Amendment extended the first set of amendments to the states, but Maxwell $v$. Dow ${ }^{91}$ rejected that argument and spoke only of the "first ten amendments" or the "first eight amendments."92 In dissent, Justice Harlan called the first set of amendments the Bill of Rights four times and said that after the First Congress " $[t]$ hese amendments have ever since been regarded as the National Bill of Rights." ${ }^{93}$ The same distinc-

85 In 1871, a lawyer mentioned the "great bill of rights contained in the amendments," in an argument before the Supreme Court. See Knox v. Lee, 79 U.S. (12 Wall.) 457, 506 (1871) (oral argument of Clarkson Potter). After that, I cannot find any significant cites during the 1870 s.

8683 U.S. (16 Wall.) 36, 67 (1873).

$87 \quad I d$.

88 Kring v. Missouri, 107 U.S. 221, 226 (1883).

89 Id.

90 Spies v. Illinois, 123 U.S. 131, 166 (1887); see id. at 151 (oral argument of John Randolph Tucker).

91176 U.S. 581 (1900).

92 See, e.g., id. at 586 ("[T]he first ten amendments to that instrument were proposed to the legislatures of the several States by the first Congress on the 25th of September, 1789."); id. at 587 ("It is now urged in substance that all the provisions contained in the first ten amendments, so far as they secure and recognize the fundamental rights of the individual as against the exercise of Federal power, are by virtue of [the Fourteenth] amendment to be regarded as privileges or immunities of a citizen of the United States . . ."); id. at 597 ("We have cited these cases for the purpose of showing that the privileges and immunities of citizens of the United States do not necessarily include all the rights protected by the first eight amendments to the Federal Constitution . . .."); id. at 601 (referring again to "the first eight amendments to the Constitution").

$93 I d$. at 607 (Harlan, J., dissenting); see id. at 614 (discussing procedures "expressly forbidden in the National Bill of Rights"); $i d$. at 616 (referring to the "privileges and 
tion was present when the Court reaffirmed Maxwell eight years later. ${ }^{94}$ While Justice Harlan continued to champion the Bill of Rights in dissent, the Court responded with only a grudging comment on the "rights which are enumerated in the first eight Articles of amendment to the Federal Constitution, sometimes called the Federal Bill of Rights." 95

Sometimes? This is a far cry from the document that is now venerated at the National Archives. What is important to note here, though, is that the Court's unwillingness to call the 1791 amendments a bill of rights was motivated by its resistance to incorporation rather than any formal view of what a bill of rights was. ${ }^{96}$ I say that in part because when another attempt to increase federal power was made at around the same time that leaned on the first set of amendments in a more acceptable way, the Justices were happy to embrace the term.

\section{IMPERIALISM}

This Part explores how the "Bill of Rights" made further inroads into constitutional discourse during the debate over the validity of ruling colonies that would never be admitted as states. International affairs often exert significant influence on domestic constitutional law, but the relationship between foreign policy and the Bill of Rights is not explored in the academic literature. ${ }^{97}$ Both supporters and opponents of acquiring the Philippines following the Spanish-American War found the Bill of Rights a useful instrument to express their views on colonialism. ${ }^{98}$ Congress responded by giving a limited version of the first set of amendments to the islands, which was

immunities specified in the National Bill of Rights"); $i d$. at 617 (mentioning the "guarantees of life and liberty which are found in the National Bill of Rights"). Justice Harlan appears to be the first person who claimed that the Framers as a whole called the first set of amendments the Bill of Rights.

94 See Twining v. New Jersey, 211 U.S. 78 (1908).

95 Id. at 98; see id. at 120 (Harlan, J., dissenting) (invoking the Bill of Rights).

96 This observation draws support from the fact that in other domestic cases in the 1890s the Court was comfortable with "the Bill of Rights," so long as incorporation was not the issue presented. See King v. Mullins, 171 U.S. 404, 422 (1898) ("By the Magna Charta it is declared that no citizen shall be disseized of his freehold or be condemned but by the lawful judgment of his peers or by the law of the land. The substance of this declaration is contained in our Bill of Rights."); Robertson v. Baldwin, 165 U.S. 275, 281 (1897) ("The law is perfectly well settled that the first ten amendments to the Constitution, commonly known as the Bill of Rights, were not intended to lay down any novel principles of government, but simply to embody certain guaranties and immunities which we had inherited from our English ancestors ....”).

97 Some examples of this influence include the European conflict following the French Revolution, which led to the Alien and Sedition Acts and the Virginia and Kentucky Resolutions, and the Cold War.

98 See President McKinley Defines His Position, N.Y. Times, Sept. 10, 1900, at 2 [hereinafter McKinley's Statement] (quoting the Philippine interim authority, which said the islands should receive "substantially all rights described in the Bill of Rights in the Federal Constitution"); see also Bryan's Speech, supra note 15, at 8 (arguing that the bill of rights should apply to the new colonies). 
enough to reconcile the public to this unprecedented increase in federal authority.

\section{A. The Spanish-American War and the Philippines}

The acquisition of permanent colonies by a nation born in rebellion was troubling to many Americans, and the Bill of Rights supplied some critical vocabulary for working through those fears. ${ }^{99}$ Shortly after the SpanishAmerican War ended, Senator George Vest said that anyone who thought that "the privileges guaranteed by the bill of rights" did not extend to foreign subjects of the United States was guilty of asserting "a monstrous proposition." 100 After William Jennings Bryan addressed a group of Kentucky Democrats in June 1899, they issued a resolution rejecting "the imperialistic policy of the National Administration toward the Filipinos as repugnant to the Bill of Rights." 101 Doubts about the legitimacy of federal rule over distant lands as permanent colonies only deepened when a bloody rebellion began in the Philippines against the occupation. ${ }^{102}$

In response to this political challenge, President William McKinley turned to the first set of amendments. The President issued instructions to the interim government in the Philippines (led by William Howard Taft) listing most of the provisions in the First, Fourth, Fifth, Sixth, and Eighth Amendments and ordering that they "be established and maintained in their islands for the sake of their liberty and happiness." 103 The President, however, did not describe this list as a bill of rights or offer the same protections to Puerto Rico, which opened the door for Bryan to charge in his address accepting the Democratic presidential nomination that McKinley claimed "the right to treat millions of people as mere 'possessions' and deal with them unrestrained by the Constitution or the Bill of Rights." ${ }^{04}$ Bryan's speech marked the first time that a bill of rights was part of a national campaign since the ratification debate on the Constitution itself.

99 The late 1890s also marked a significant constitutional transition on issues such as race and economic regulation. See generally Gerard N. Magliocca, The Tragedy of WiLliam Jennings Bryan: Constitutional Law and the Politics of Backlash (2011) (providing a broad overview of this era).

100 Vest Against Expansion, N.Y. Times, Dec. 13, 1898, at 1.

101 Ohio Valley Bimetallists, N.Y. Times, Jun. 3, 1899, at 4.

102 See Doris Kearns Goodwin, The Bully Pulpit: Theodore Roosevelt, William Howard Taft, and the Golden Age of Journalism 267 (2013) (discussing the insurgency and the brutal methods used by American troops in response to the rebellion); see also National Party Platforms, supra note 15, at 113 (quoting the Democratic Platform in 1900 , which stated that the "issue of imperialism growing out of the Spanish war involves the very existence of the Republic and the destruction of our free institutions").

103 See Kepner v. United States, 195 U.S. 100, 122-23 (1904) (quoting the President's instructions); GoodwIN, supra note 102, at 265 (discussing Taft's appointment). McKinley included some other constitutional rights in his list, such as the prohibitions on slavery, ex post facto laws, and bills of attainder. See Kepner, 195 U.S. at 123.

104 See Bryan's Speech, supra note 15, at 8; see also Michael Kazin, A Godly Hero, The Life of William Jennings Bryan 103-04 (2006) (discussing this speech). 
Less than two weeks after Bryan's statement, the provisional government in the Philippines explicitly stated that the Bill of Rights would apply there. ${ }^{105}$ Replying to a telegram from Secretary of War Elihu Root requesting a progress report, the interim authority said that within eighteen months there would be a territorial government "under which substantially all rights described in [the] bill of rights in [the] Federal Constitution are to be secured to the people of the Philippines."106 A few weeks after that, President McKinley issued a written statement accepting the Republican presidential nomination and quoted this line from the report. ${ }^{107}$ There is no proof that the interim authority's statement was a response to Bryan's speech, but McKinley's use of that reference almost certainly was.

\section{B. The Supreme Court and Colonialism}

When the Supreme Court and Congress grappled with the constitutionality of regulating the colonies after McKinley's victory over Bryan, the first set of amendments and the Bill of Rights loomed large in their thinking. The first case to address the new territories, decided in 1901, held that some of the Article 1 limits on Congress's power to raise revenue did not apply to Puerto Rico. ${ }^{108}$ But the Court added that it was not "expressing an opinion how far the bill of rights contained in the first eight amendments is of general and how far of local application." 109 (Remember that this was the same Court that one year earlier refused to call the same eight amendments the bill of rights in Maxwell. ${ }^{110}$ ) In 1902, Congress codified the rights in those amendments that were being observed by the interim government in the

105 See Present Condition of the Philippine Group, N.Y. TImes, Sept. 20, 1900, at 1 (providing Aug. 21, 1900 as the date of the reply).

$106 I d$. Telegrams in this era often omitted indefinite and definite articles.

107 See McKinley's Statement, supra note 98, at 2. The only prior reference to the Bill of Rights was in James Buchanan's 1860 Annual Message, which talked about "the bill of rights which secures the people against any abuse of power by the Federal Government" and the First Amendment as part of a discussion rejecting secession. James Buchanan, Annual Message (Dec. 3, 1860), in 5 Messages, supra note 28, at 637 (1903). In 1880, President Rutherford B. Hayes quoted a Supreme Court opinion stating that the federal government's powers were "restrained by a sufficiently rigid bill of rights," but it is unclear if that was a reference to the first set of amendments or to Article I, Section 9. See Rutherford B. Hayes, Veto Message (June 15, 1880), in 7 Messages, supra note 28, at 594 (1908); see also Ex Parte Siebold, 100 U.S. (10 Otto) 371, 394 (1880); Barron v. Baltimore, 32 U.S. (7 Cranch) 243, 248 (1833). In 1867, President Andrew Johnson said the "military must be kept, according to the language of our bill of rights, in strict subordination to the civil authority," Andrew Johnson, Veto Message (Mar. 23, 1867), in 6 Messages, supra note 28, at 535 (1909), but he was quoting Daniel Webster's invocation of the Massachusetts Bill of Rights. See Daniel Webster, The First Bunker Hill Monument Oration (June 17, 1843) in Fred Newton Scott, Daniel Webster's First Bunker Hill Oration 27, 48 (1895).

108 See Downes v. Bidwell, 182 U.S. 244, 249 (1901) (stating that the case involved tariff provisions in Article I, Section 8 and Article I, Section 9); id. at 287 (stating the holding that the relevant provisions did not apply to Puerto Rico).

$109 I d$. at 277; see id. at 279 (referring to "other privileges of the bill of rights").

110 See supra text accompanying notes 91-92. 
Philippines. ${ }^{111}$ This Organic Act did not call those protections a bill of rights, though contemporary news accounts used that term. ${ }^{112}$

When the Justices started hearing appeals from the Philippines under the 1902 Act, though, they repeatedly described what Congress enacted as a bill of rights. ${ }^{113}$ Kepner $v$. United States ${ }^{114}$ was the most important of these cases, as the Court stated that McKinley's intent in his instructions was "to give much of the beneficent protection of the $[\mathrm{B}]$ ill of $[\mathrm{R}]$ ights to the people of the Philippine Islands." 115 His words, the Court stated, "are not strange to the American lawyer or student of constitutional history. They are the familiar language of the Bill of Rights, slightly changed in form, but not in substance, as found in the first nine amendments to the Constitution of the United States." 116 (This is the only time that the Court ever defined the Bill of Rights as the first nine amendments. ${ }^{117}$ ) "When Congress came to pass the [A]ct of July 1, 1902," the Court said, "it enacted, almost in the language of the President's instructions, the Bill of Rights of our Constitution." 118

111 See The Philippine Organic Act, Pub. L. No. 57-235, 32 Stat. 691 (1902); Kepner v. United States, 195 U.S. 100, 117-19 (1904) (quoting section 5 of the Act).

112 See, e.g., The "Bill of Rights" for the Filipinos, N.Y. Times, May 30, 1902, at 3 (describing the markup of the Philippine Organic Act).

113 See Ocampo v. United States, 234 U.S. 91, 94 (1914) (calling section 5 of the Organic Act "the Philippine Bill of Rights"); Tiaco v. Forbes, 228 U.S. 549, 557 (1913) (same); Dowdell v. United States, 221 U.S. 325, 329 (1911) (naming "the so-called Philippine Bill of Rights, which is substantially taken from the Bill of Rights of the Federal Constitution" (citing Kepner v. United States, 195 U.S. 100)); Weems v. United States, 217 U.S. 349, 365 (1910) (mentioning "the [B]ill of [R]ights of the islands"); Cariño v. Insular Gov't, 212 U.S. 449, 459 (1909) (stating that the Organic Act "made a bill of rights embodying the safeguards of the Constitution"); Flemister v. United States, 207 U.S. 372, 375 (1907) (referring to the Philippine Bill of Rights); Paraiso v. United States, 207 U.S. 368, 369-70 (1907) (citing the Philippine Bill of Rights twice); Serra v. Mortiga, 204 U.S. 470, 474 (1907) (describing "the [B]ill of [R]ights enacted by Congress for the Philippine Islands"); Trono v. United States, 199 U.S. 521, 528 (1905) (stating that the language from the Organic Act "is substantially taken from the Bill of Rights set forth in the Amendments to the Constitution”); $c f$. Yu Cong Eng v. Trinidad, 271 U.S. 500, 518 (1926) (stating, in an appeal from the Philippines, that the Court was "likely thus to trespass on the provision of the Bill of Rights that the accused is entitled to demand the nature and cause of the accusation against him").

114195 U.S. 100 (1904).

115 Id. at 122.

$116 I d$. at 123.

117 The reference to the first nine amendments is fascinating, as the Philippine Bill of Rights did not include the Ninth Amendment. See The Philippine Organic Act, Pub. L. No. 57-235, § 5, 32 Stat. 691, 692 (1902). If one reads the Bill of Rights as the 1791 amendments that protect personal rights and thinks that the Ninth Amendment guarantees unwritten individual rights, then calling the first nine amendments the Bill of Rights makes a lot of sense.

118 Kepner, 195 U.S. at 124; see id. ("In view of the expressed declaration of the President, followed by the action of Congress, both adopting, with little alteration, the provisions of the Bill of Rights ...."). 
\begin{tabular}{lllll}
\hline |jciprod01 1 productnWNNDL192-1WDL105.txt & unknown & Seq: 21 & 9-NOV-16 & 11:50 \\
\hline
\end{tabular}

2016]

THE BILL OF RIGHTS AS A TERM OF ART

Kepner was the capstone for the use of the Bill of Rights to justify the expansion of federal authority that colonialism required. The formalities of a bill of rights that were important to the framers were absent from the Philippine Bill of Rights. ${ }^{119}$ Nobody cared that parts of the first set of amendments, such as the right to own a gun and the right to a criminal jury trial, were omitted from what was granted by Congress. The key point was that something called a bill of rights with some protections applied there. This term soothed domestic qualms about imperialism and was a model for the Organic Acts adopted subsequently for Puerto Rico and the Panama Canal Zone. ${ }^{120}$ The difference between colonialism and incorporation with respect to a bill of rights was that one was the product of a national consensus while the other was not. The Court's eagerness to call the first set of amendments the Bill of Rights in the former case and its unwillingness to do so in the latter one is hard to explain as anything other than a functional choice shaped by its response to the specific claim of federal power.

$$
* * *
$$

The use of the Bill of Rights to validate imperialism raised the profile of that term of art, but the pace of that change should not be overstated. For example, from 1908 until 1939 the Supreme Court referred to the Bill of Rights in only six cases that were not from the Philippines or Puerto Rico. ${ }^{121}$

119 See The Philippine Organic Act $§ 5$, 32 Stat. 691, 692 (1902) (listing the rights in a bare-bones fashion). The association made between the first set of amendments and the Bill of Rights in the colonial legal materials also probably helped displace the traditional or formal definition, though cause and effect is difficult to establish.

120 See Puerto Rican Federal Relations Act of 1917, Pub. L. No. 64-368, § 2, 39 Stat. 951 (extending some portions of the first set of amendments to Puerto Rico); see also Balzac v. Porto Rico, 258 U.S. 298, 306 (1922) (stating that "the second section of the act is called a 'Bill of Rights'”); Gerald L. Neuman, Closing the Guantanamo Loophole, 50 Loy. L. Rev. 1, 18 (2004) (stating that President Theodore Roosevelt issued an executive order applying portions of the first set of amendments to the Panama Canal Zone that was codified by Congress in 1934).

121 See Palko v. Connecticut, 302 U.S. 319, 323 (1937) (stating Palko's argument as " $[\mathrm{w}]$ hatever would be a violation of the original bill of rights (Amendments I to VIII) if done by the federal government is now equally unlawful by force of the Fourteenth Amendment if done by a state"); $i d$. at 326 ("We reach a different plane of social and moral values when we pass to the privileges and immunities that have been taken over from the earlier articles of the $[\mathrm{F}]$ ederal $[\mathrm{B}]$ ill of $[\mathrm{R}]$ ights and brought within the Fourteenth Amendment by a process of absorption."); Ex Parte Grossman, 267 U.S. 87, 117 (1925) ("Contempt proceedings are sui generis because they are not hedged about with all the safeguards provided in the bill of rights for protecting one accused of ordinary crime from the danger of unjust conviction."); $i d$. at 122 ("The power of a court to protect itself and its usefulness by punishing contemnors is of course necessary, but it is one exercised without the restraining influence of a jury and without many of the guaranties which the bill of rights offers to protect the individual against unjust conviction.”); Mo. Pac. Ry. Co. v. Kansas, 248 U.S. 276, 281 (1919) (referencing "the first ten amendments to the Constitution embodying a bill of rights"); Mutual Film Corp. v. Hodges, 236 U.S. 248, 251 (1915) (stating petitioner's allegation that a statute "violates the $[\mathrm{B}]$ ill of $[\mathrm{R}]$ ights of the United States and of the State of Kansas"); Weeks v. United States, 232 U.S. 383, 390 (1914) (stating that 
During this era, the Court was more likely to say the "first ten amendments" or the "first eight amendments" than the Bill of Rights, although the terms were now interchangeable. ${ }^{122}$ There were more references to the Bill of Rights in official, academic, and popular discourse by the 1910s, but this was still rather limited. ${ }^{123}$ For instance, when President Woodrow Wilson discussed a bill of rights in his 1915 Annual Message to Congress, he was talking about the Virginia Declaration of Rights. ${ }^{124}$ President Wilson never referred to the 1791 amendments as the Bill of Rights.

In sum, by the early twentieth century the Bill of Rights was used in the modern sense on a semi-regular basis, but there was still no agreement that this text was constitutional gospel. To understand how that changed, we must listen to Franklin D. Roosevelt as he used the Bill of Rights to support the growth of national authority to fight the Great Depression and Nazi Germany.

the Fourth Amendment "took its origin in the determination of the framers of the Amendments to the Federal Constitution to provide for that instrument a Bill of Rights"); Noble State Bank v. Haskell, 219 U.S. 104, 110 (1911) (discussing "the great guarantees in the Bill of Rights").

122 The Court referred to the first ten amendments seven times. See Coleman v. Miller, 307 U.S. 433, 453 (1939) (describing the average time for the states to ratify a constitutional amendment "since the first ten amendments"); United States v. Carolene Prods. Co., 304 U.S. 144, 152 n.4 (1938) (explaining the presumption of constitutionality was narrower when a statute was within the ambit of specific prohibitions "such as those of the first ten amendments”); Patton v. United States, 281 U.S. 276, 298 (1930) (explaining that the "first ten amendments and the original Constitution" should be read together because they were ratified at the same time); $i d$. at 300 (stating that the Judiciary Act of 1789 was passed the day before the first ten amendments were proposed); Gaines v. Washington, 277 U.S. 81,85 (1928) (stating that it was well settled "that the first ten [a]mendments apply only to the procedure and trial of causes in the federal courts"); Myers v. United States, 272 U.S. 52, 174 (1926) ("It was the Congress that rounded out the Constitution itself by the proposing of the first ten amendments.”); Minneapolis \& St. Louis R.R. Co. v. Bombolis, 241 U.S. 211, 217 (1916) (stating that the first ten amendments "are not concerned with state action"); Jack v. Kansas, 199 U.S. 372, 379-80 (1905) (referring to the first ten amendments). In three cases, the Court spoke of the "first eight amendments." See Grosjean v. Am. Press Co., 297 U.S. 233, 243-44 (1936) ("We concluded that certain fundamental rights, safeguarded by the first eight amendments against federal action, were also safeguarded against state action.”); Powell v. Alabama, 287 U.S. 45, 67 (1932) (referring to "the personal rights safeguarded by the first eight Amendments"); United States v. Lanza, 260 U.S. 377, 382 (1922) (stating that the "guaranties in the first eight amendments" applied to only federal action (citing Barron v. Baltimore, 32 U.S. 243 (1833))).

123 One notable example of the modern usage was Felix Frankfurter's Note. See Felix Frankfurter, The Present Approach to Constitutional Decisions on the Bill of Rights, 28 HARv. L. REv. 790 (1915). In fact, a Westlaw search indicates that this was the only piece of academic scholarship prior to World War II that had the phrase "bill of rights" in its title.

124 Woodrow Wilson, Third Annual Message (Dec. 7, 1915), in 35 The PAPERs of WoOdrow Wilson 295 (Arthur S. Link ed., 1980). 


\section{The New Deal and World War II}

This Part examines how the Bill of Rights became essential to constitutional discourse during the 1930s and 1940s in the name of more federal power. The seminal figure in this transformation was President Roosevelt, who discussed the Bill of Rights in many high-profile speeches from 1934 to 1944. In these statements, the President was responding to concerns about the validity of the New Deal and about the threat posed by the Third Reich. When the sesquicentennial of ratification arrived on December 15th, 1941, the first national "Bill of Rights Day" was celebrated and FDR delivered a radio address that made that text the centerpiece of the fight against Hitler. ${ }^{125}$ Later in the midst of war, the President again called on the Bill of Rights to explain how a bright future would come only after another round of federal action to create economic entitlements.

\section{A. The Master Politician}

In June 1934, Franklin D. Roosevelt took to the airwaves and used the Bill of Rights to respond to criticism of the New Deal. ${ }^{126}$ After touting his Administration's early successes, Roosevelt said that "[p]lausible self-seekers and theoretical diehards will tell you of the loss of individual liberty" that Americans were facing as a result of the new programs. ${ }^{127}$ "Answer this question," he asked, "out of the facts of your own life. Have you lost any of your rights or liberty or constitutional freedom of action and choice?"128 Roosevelt then defined those rights as "the Bill of Rights of the Constitution, which I have solemnly sworn to maintain and under which your freedom rests secure."129 "Read each provision of that Bill of Rights," he concluded, "and ask yourself whether you personally have suffered the impairment of a single jot of these great assurances. I have no question in my mind as to what your answer will be."130

This Fireside Chat contained the most visible presidential reference to the Bill of Rights in decades, but the more important point was how FDR used the Bill of Rights. As with incorporation and colonialism, the Bill of Rights was again being summoned to legitimate federal power. Roosevelt was implying that any federal action that complied with those provisions was not a problem for freedom, which was a direct challenge to the doctrines of enumerated powers and federalism that were also supposed to guard liberty. ${ }^{131}$

125 See Wertheimer, supra note 8, at 18-25. My book on the Bill of Rights will talk in greater detail about how that text was viewed in popular culture during the first half of the twentieth century. See also Michael Kammen, A Machine That Would Go of Itself 337-53 (1986) (giving an excellent overview of that subject); infra Section V.B.

126 See Fireside Chat, supra note 18, at 49.

127 Id.

$128 I d$.

$129 I d$.

130 Id.

131 In a sense, the New Deal's vision of federal power was the same as the sweeping authority that Congress possessed over the Philippines and the other colonies. There were 
This rhetorical move could only work, however, if people believed that the Bill of Rights was set apart from the rest of the Constitution.

FDR's next meditation on the Bill of Rights and the role of the federal government came in his 1937 Constitution Day Address. ${ }^{132}$ Before a large crowd at the Washington Monument, the President declared victory in his fight with the Supreme Court over the legality of the New Deal and commented: "[O]ur constitutional democratic form of government must meet the insistence of the great mass of our people that economic and social security and the standard of American living be raised." 133 "Only by succeeding in that," he said, "can we ensure against internal doubt as to the worthwhileness of our democracy and dissipate the illusion that the necessary price of efficiency is dictatorship with its attendant spirit of aggression." 134 FDR stated that he "refuse[d] to forget that the Bill of Rights was put into the Constitution not only to protect minorities against intolerance of majorities, but to protect majorities against the enthronement of minorities."135 "Nothing would so surely destroy the substance of what the Bill of Rights protects than its perversion to prevent social progress," and moreover " $\mathrm{t}] \mathrm{he}$ surest protection of the individual and of minorities is that fundamental tolerance and feeling for fair play which the Bill of Rights assumes." ${ }^{136}$ Sadly, "tolerance and fair play would disappear here as it has in some other lands if the great mass of people were denied confidence in their justice, their security and their self-respect." 137

no enumerated powers or federalism principles that limited what Congress could do there, and thus that broad power that required the Bill of Rights for justification in circumstances that reached beyond the traditional territorial situation. When FDR sought to arm Congress with the same sort of sweeping authority over the national economy, the Bill of Rights was again called upon to provide the necessary validation.

132 See Constitution Day Address, supra note 20, at 359-67; cf. Wertheimer, supra note 8 , at 12 ("FDR himself instructed post office muralists who were charged with commemorating the Constitution's 150th anniversary in 1937 to emphasize the addition of the Bill of Rights instead of the ratification of the Constitution itself.").

133 Constitution Day Address, supra note 20, at 361-62; see Jeff Shesol, Supreme Power: Franklin Roosevelt Vs. the Supreme Court 517 (2010) (describing the event).

134 Constitution Day Address, supra note 20, at 362.

$135 I d$. at 366.

136 Id. Consider for a moment how Roosevelt contrasted the Bill of Rights with Congress's Article I powers: "When the Framers were dealing with what they rightly considered eternal verities," he said,

unchangeable by time and circumstance, they used specific language. . . . With almost equal definiteness they detailed the Bill of Rights.

But when they considered the fundamental powers of the new national government they used generality, implication and statement of mere objectives, as intentional phrases which flexible statesmanship of the future, within the Constitution, could adapt to time and circumstance.

Id. at 363. On this reading, the Bill of Rights was a list of specifics that illustrated the breadth of Congress's authority, not a broad set of limits of that authority.

137 Id. at 366. 
\begin{tabular}{lllll}
\hline \iciprod01 1 productnWWNDL $92-1$ NDL105.txt & unknown & Seq: 25 & 9-NOV-16 & 11:50 \\
\hline
\end{tabular}

2016]

In this passage, FDR was essentially saying that support for the New Deal was the only way to save the Bill of Rights from fascism or communism. ${ }^{138}$ While this reinforced his theme that the Bill of Rights was a critical part of the Constitution worth saving, the President was also connecting the spread of tyranny with the importance of the Bill of Rights. The flagrant violation of the rights listed in the first set of amendments by Hitler and Stalin increased their visibility, but FDR was going further and implying that interpreting the Bill of Rights to prohibit federal regulation of property gave domestic demagogues the material that they needed to destroy the Bill of Rights. ${ }^{139}$ Once again, developments overseas were changing the meaning and the relevance of the Bill of Rights.

\section{B. The Bill of Rights Goes to War}

The year 1939 was the sesquicentennial of the amendments proposed by the First Congress, and the President marked the occasion in a speech to a Joint Session of Congress that began the process of using the Bill of Rights for a new political goal: building support for federal action to prepare for war. ${ }^{140}$ FDR began this part of his address by stating:

$[\mathrm{T}]$ here came about that tacit understanding that to the Constitution would be added a Bill of Rights. Well and truly did the first Congress of the United States fulfill that first unwritten pledge; and the personal guarantees thus given to our individual citizens have established, we trust for all time, what has become as ingrained in our American natures as the free elective choice of our representatives itself. ${ }^{141}$

After endorsing the myth that the Bill of Rights (as opposed to the first set of amendments) was written into the Constitution in 1791, the President pivoted to current events. "In that Bill of Rights," he said, "lies another vast chasm between our representative democracy and those reversions to personal rule which have characterized these recent years." 142

The President's claim that the Bill of Rights was an important component of American exceptionalism drove the rest of his oration, which compared some specific provisions in the Bill of Rights with the practices in Nazi Germany and the Soviet Union. One example was the right to a jury trial, as

138 See id. at 365-66 (“[M] odern history proves that reforms too long delayed or denied have jeopardized peace, undermined democracy, and swept away civil and religious liberties.").

139 Cf. Alan Brinkley, Voices of Protest: Huey Long, Father Coughlin, and the Great Depression (1982) (discussing illiberal opposition to the New Deal).

140 See 150th Anniversary of Congress Address, supra note 19, at 147-53.

141 Id. at 152.

142 Id.; cf. Franklin D. Roosevelt, Third Inaugural Address (Jan. 20, 1941) in 1941 Roosevelt PAPERs, supra note 17, at 4 ("The Bill of Rights remains inviolate."); Franklin D. Roosevelt, Opening of the 1939 New York's World's Fair (Apr. 30, 1939), in 1939 RoOsevelt PAPERs, supra note 17, at 298 (1941) (hailing our "sacred Bill of Rights, which guaranteed and has maintained personal liberty through freedom of speech, freedom of the press, freedom of religion and freedom of assembly"). 
Roosevelt asked whether "the people of our own land ever stop to compare that blessed right of ours with some processes of trial and punishment which of late have reincarnated the so-called 'justice' of the dark ages?"143 The President posed a similar question about the Takings Clause, wondering whether we would ever "willingly abandon our security against that in the face of the events of recent years?" 144 Then there was the freedom of religion: "Where democracy is snuffed out, where it is curtailed, there, too, the right to worship God in one's own way is circumscribed or abrogated." 145 "Shall we by our passiveness, by our silence, by assuming the attitude of the Levite who pulled his skirts together and passed by on the other side," FDR asked, "lend encouragement to those who today persecute religion or deny it?" 146 "The answer to that is 'no' today," he said, "just as in the days of the first Congress of the United States it was "no." "147 He ended with: "We believe in the other freedoms of the Bill of Rights, the other freedoms that are inherent in the right of free choice by free men and women." 148

FDR used the Bill of Rights to attack totalitarianism as part of an extended campaign to convince the nation to support a peacetime military draft-the most intrusive of all federal acts. In his speech accepting the Democratic nomination for a third term as President, Roosevelt declared: "It is our credo-unshakable to the end-that we must live under the liberties that were first heralded by Magna Carta and placed into glorious operation through the Declaration of Independence, the Constitution of the United States and the Bill of Rights."149 "The Government of the United States," he went on,

for the past seven years has had the courage openly to oppose by every peaceful means the spread of the dictator form of Government. If our Government should pass to other hands next January-untried hands, inexperienced hands-we can merely hope and pray that they will not substitute appeasement and compromise with those who seek to destroy all democracies everywhere, including here. ${ }^{150}$

143 150th Anniversary of Congress Address, supra note 19, at 152.

$144 I d$. It is not clear what the President was referring to here, though he could have meant the seizure of private land under communism or the taking of Jewish property by the Nazis.

145 Id. at 153.

$146 I d$. In this passage the persecutors of religion were Nazis and the deniers of religion were communists.

147 Id.

148 Id. FDR's endorsement of the Bill of Rights received a symbolic boost from the states that chose not to support the first set of amendments in 1791. Massachusetts, Connecticut, and Georgia decided to make the original thirteen unanimous by ratifying the Bill of Rights in 1939. MAIER, supra note 8, at 459 .

149 Acceptance Speech, supra note 21; see also Franklin D. Roosevelt, Annual Message to the Congress (Jan. 4, 1939), in 1939 Roosevelt PAPERs, supra note 17, at 6 (1941) (stating that the New Deal's success came "without any dictator's power to command, without conscription of labor or confiscation of capital, without concentration camps and without a scratch on freedom of speech, freedom of the press or the rest of the Bill of Rights").

150 Acceptance Speech, supra note 21. 
Defending the Bill of Rights without appeasement and compromise required a draft, which was enacted later in $1940 .{ }^{151}$

Popular and official fervor for the first set of amendments reached a peak on Bill of Rights Day in December 1941. This was the first time that the anniversary of the ratification was celebrated, and tens of millions of Americans participated in the festivities, which were endorsed by Congress and by many state and local officials. ${ }^{152}$ In his Bill of Rights Day Proclamation, Roosevelt praised "the great American charter of personal liberty and human dignity" and noted that the anniversary was especially poignant for

those institutions of a democratic people which owe their very existence to the guarantees of the Bill of Rights: the free schools, the free churches, the labor unions, the religious and educational and civic organizations of all kinds which, without the guarantee of the Bill of Rights, could never have existed. 153

He said that those "who have seen these privileges lost in other continents and other countries can now appreciate their meaning to those people who enjoyed them once and now no longer can."154 "[B]y that realization," the President concluded, "we have come to a clearer conception of their worth to us, and to a stronger and more unalterable determination that here in our land they shall not be lost or weakened or curtailed." 155

Bill of Rights Day was established before the United States entered World War II, and by happenstance the event fell just eight days after Pearl Harbor. It was a moment of intense patriotism. In Chicago, the mayor read the Bill of Rights aloud downtown, while on Wall Street the governors of New York and Virginia participated in a ceremony to show sectional unity on the Bill of Rights and on the war effort. ${ }^{156}$ That night, tens of millions of Americans listened to a radio show on the Bill of Rights entitled "We Hold These Truths" narrated by Jimmy Stewart and including performances by Lionel

151 See generally Selective Training and Service Act of 1940, Pub. L. No. 76-783, 54 Stat. 885 (1940) (establishing a national draft).

152 See Franklin D. Roosevelt, Bill of Rights Day Proclamation (Nov. 27, 1941), in 1941 Roosevelt Papers, supra note 17, at 497 ("Whereas a Joint Resolution of the Congress, approved August 21, 1941, authorizes and requests the President of the United States 'to issue a proclamation designating December 15, 1941, as Bill of Rights Day' . . . Now, THEREFore, I, Franklin D. Roosevelt, President of the United States of America, do hereby designate December 15, 1941, as Bill of Rights Day." (quoting H.R.J. Res. 120, 77th Cong. (1941)); Wertheimer, supra note 8, at 19 (stating that nineteen governors and eighty-six mayors officially sanctioned "Bill of Rights" Day); see also id. at 22 (describing the diverse coalition of religious and secular groups that were avid supporters of Bill of Rights Day).

153 Franklin D. Roosevelt, Bill of Rights Day Proclamation (Nov. 27, 1941), in 1941

Roosevelt Papers, supra note 17, at 498.

$154 I d$.

155 Id. at 498-99.

156 Wertheimer, supra note 8, at 19-20. 
Barrymore, Orson Welles, and Edward G. Robinson. ${ }^{157}$ Barrymore intoned that the program was about "a document that men have fought for, that men are fighting for, that men will keep on fighting for as long as freedom is a strong word falling sweet upon the ear."158

These commemorations were capped by a major presidential speech that made the Bill of Rights into a weapon against Hitler and was, in effect, our declaration of war against the Nazis. ${ }^{159}$ Addressing his audience as "Free Americans," FDR began this way:

No date in the long history of freedom means more to liberty-loving men in all liberty-loving countries than the fifteenth day of December, 1791. On that day, 150 years ago, a new Nation, through an elected Congress, adopted a declaration of human rights which has influenced the thinking of all mankind from one end of the world to the other. There is not a single Republic of this hemisphere which has not adopted in its fundamental law the basic principles of freedom of man and freedom of mind enacted in the American Bill of Rights.

There is not a country, large or small, on this continent and in this world which has not felt the influence of that document, directly or indirectly.

Indeed, prior to the year 1933, the essential validity of the American Bill of Rights was accepted everywhere at least in principle. Even today, with the exception of Germany, Italy, and Japan, the peoples of the whole world-in all probability four-fifths of them-support its principles, its teachings, and its glorious results. ${ }^{160}$

After that stirring introduction, the President made his case against the Third Reich. "[I]n the year 1933," he stated, "there came to power in Germany a political clique which did not accept the declarations of the American bill of human rights as valid: a small clique of ambitious and unscrupulous politicians whose announced and admitted platform was precisely the destruction of the rights that instrument declared."161 "Indeed," he said, "the entire program and goal of these political and moral tigers was nothing more than the overthrow, throughout the earth, of the great revolution of human liberty of which our American Bill of Rights is the mother charter."162

157 See id. at 20-21; see also dabitx, We Hold These Truths with Jimmy Stewart, YouTube (Dec. 5, 2012), http://www.youtube.com/watch?v=6f6LIfSnctY (showing a December 15, 1941, radio broadcast on CBS, NBC Blue, NBC Red, and Mutual).

158 This line was spoken in the opening few minutes of the broadcast. See dabitx, supra note 157 .

159 See Franklin D. Roosevelt, Radio Address Commemorating the 150th Anniversary of the Ratification of the Bill of Rights (Dec. 15, 1941), in 1941 Roosevelt PApers, supra note 17, at 554-57. This talk came at the end of the "We Hold These Truths" radio show. I say that this was a functional war declaration because Germany declared war on December 11 th, and Roosevelt had not yet made a speech about that action.

$160 \quad I d$. at 554.

$161 I d$. at 554-55.

$162 I d$. at 555 . 
Roosevelt then offered a dark assessment of what life without the Bill of Rights looked like under Hitler. "[T] he individual human being," Roosevelt said, "has no right to a soul of his own, or a mind of his own, or a tongue of his own, or a trade of his own; or even to live where he pleases or to marry the woman he loves."163 Instead, "his only duty is the duty of obedience, not to his God, not to his conscience, but to Adolf Hitler; and that his only value is his value, not as a man, but as a unit of the Nazi state." ${ }^{164}$ He then issued this bill of indictment of the Third Reich:

To Hitler the ideal of the people, as we conceive it-the free, self-governing, and responsible people-is incomprehensible. . . .

To Hitler, the government, as we conceive it, is an impossible conception. ...

To Hitler the church, as we conceive it, is a monstrosity to be destroyed by every means at his command. . . .

To Hitler, the freedom of men to think as they please and speak as they please and worship as they please is, of all things imaginable, most hateful and most desperately to be feared. ${ }^{165}$

"What we face," FDR said, "is nothing more nor less than an attempt to overthrow and to cancel out the great upsurge of human liberty of which the American Bill of Rights is the fundamental document."166 "We will not," he concluded defiantly, "under any threat, or in the face of any danger, surrender the guarantees of liberty our forefathers framed for us in our Bill of Rights."167 Needless to say, extraordinary federal control over the economy-including rationing-was required to defend these liberties, and the Bill of Rights lent crucial symbolic support to those efforts. ${ }^{168}$

\section{A Second Bill of Rights}

The final significant speech in which President Roosevelt used the Bill of Rights to kindle support for sweeping government power was his 1944 State of the Union Address, which proposed a "second Bill of Rights."169 FDR began this part of his address by stating: "This Republic had its beginning, and grew to its present strength, under the protection of certain inalienable political rights-among them the right of free speech, free press, free wor-

$163 I d$. This appears to be the first time that an American president said that there was a right to marry, which of course reached beyond the express language of the Bill of Rights.

164 Id.

$165 I d$. at 555-56.

$166 I d$. at 556.

$167 I d$.

168 See, e.g., Emergency Price Control Act of 1942, Pub. L. No. 77-421, 56 Stat. 23 (1942) (establishing administrative authority to set price controls and ration necessities).

169 See Franklin D. Roosevelt, Message on the State of the Union (Jan. 11, 1944), in 1944 Roosevelt Papers, supra note 17, at 41. 
ship, trial by jury, freedom from unreasonable searches and seizures."170 "[A]s our industrial economy expanded," he said, "these political rights proved inadequate to assure us equality in the pursuit of happiness." 171 "We have come to a clear realization of the fact that true individual freedom cannot exist without economic security and independence. 'Necessitous men are not free men.' People who are hungry and out of a job are the stuff of which dictatorships are made." 172

Once again, the President was drawing a connection between federal inaction and the rise of tyranny, for without "this economic bill of rights," we risked returning "to the so-called "normalcy' of the 1920's," and that would mean that "though we shall have conquered our enemies on the battlefields abroad, we shall have yielded to the spirit of Fascism here at home." 173 After explaining that " $[\mathrm{w}] \mathrm{e}$ have accepted, so to speak, a second Bill of Rights under which a new basis of security and prosperity can be established for all-regardless of station, race, or creed," the President listed several positive rights that should be secured through new federal legislation. ${ }^{174}$ These included: (1) "[t] he right to a useful and remunerative job"; (2) "[t] he right to earn enough to provide adequate food and clothing and recreation"; (3) "[t] he right of every family to a decent home"; (4) "[t]he right to adequate medical care"; and (5) "[t] he right to a good education." 175

In his campaign for a fourth term that October, the President told a rally that "our Economic Bill of Rights-like the sacred Bill of Rights of our Constitution itself-must be applied to all our citizens." 176

Such an ambitious agenda would not be achieved in FDR's lifetime, and the only concrete step taken prior to his death was the enactment of benefits for returning veterans, which soon earned an appropriate nickname-the GI Bill of Rights. ${ }^{177}$ This Act of Congress was a brilliant marriage of the President's use of the Bill of Rights to further federal action on economic justice and national defense, and capped the march of the 1791 amendments from obscurity to fame. At the same time, the GI Bill of Rights illustrated the importance of global events on the growth of this core element of our Constitution.

\footnotetext{
$170 \quad I d$. at 40.

171 Id. at $40-41$.

$172 I d$. at 41.

$173 \quad I d$. at 42.

$174 I d$. at 41 . One of the rights Roosevelt listed was "freedom from unfair competition and domination by monopolies," which was a negative right. Id.

175 Id.

176 See Franklin D. Roosevelt, Campaign Address at Soldiers' Field (Oct. 28, 1944), in 1944 Roosevelt Papers, supra note 17, at 374.

177 See Servicemen's Readjustment Act of 1944, Pub. L. No. 78-346, 58 Stat. 284 (1944); cf. Martin Luther King, Jr., Why We Can't Wait 137 (1964) (“I am proposing, therefore, that, just as we granted a GI Bill of Rights to war veterans, America launch a broad-based and gigantic Bill of Rights for the Disadvantaged, our veterans of the long siege of denial.").
} 


\section{Judicial Review}

This Part assesses how the Bill of Rights became a slogan for judicial review. Our starting point here is the 1912 presidential campaign, when Republicans who supported President Taft against Theodore Roosevelt for the party's nomination turned to the Bill of Rights to discredit TR's plan for recalling state judicial decisions. ${ }^{178}$ Following the collapse of the Court's traditional jurisprudence in 1937, the Bill of Rights gave the Justices a lifeline to resurrect their authority, and Justice Robert H. Jackson responded with his elegant opinion in West Virginia State Board of Education v. Barnette, ${ }^{179}$ which is canonical in part because it stressed the connection between the Bill of Rights and judicial review. ${ }^{180}$ And when the Court was presented with the tricky issue of whether married couples could be barred from using contraceptives, Griswold v. Connecticut ${ }^{181}$ used a holistic reading of the Bill of Rights to find a constitutional right of privacy. ${ }^{182}$

\section{A. The Rough Rider}

Teddy Roosevelt needed a powerful issue to defeat a sitting President for his party's nomination, and his gambit was to call for giving voters the authority to recall decisions by state courts. ${ }^{183}$ In a speech to Ohio's Constitutional Convention in 1912, TR contended:

When a judge decides a constitutional question, when he decides what the people as a whole can and cannot do, the people should have the right to recall that decision if they think that it is wrong. We should hold the judiciary in all respect, but it is both absurd and degrading to make a fetish of a judge. ${ }^{184}$

Roosevelt singled out a case in New York striking down the state workers' compensation statute on due process grounds as "flagrant in its defiance of right and justice" and "short-sighted in its inability to face the changed needs of our civilization." 185

The Party establishment rejected Roosevelt (and his recall proposal) and framed its opposition as support for the "Bill of Rights." New York's Republi-

178 See, e.g., Root Warns Party Against the Recall, N.Y. Times, June 19, 1912, at 4 [hereinafter Root Address] (reproducing the Keynote Address at the 1912 Republican Convention, which defended President Taft and stated a commitment to "hold sacred the declarations and prohibitions of the Bill of Rights").

179319 U.S. 624 (1943).

180 See id. at 638.

181381 U.S. 479 (1965).

182 See id. at 484.

183 See Edmund Morris, Colonel Roosevelt 167-68 (2010) (describing Roosevelt's speech to the 1912 Ohio Constitutional Convention); Roosevelt Indorses Recall of Judges, N.Y. Times, Feb. 22, 1912, at 5.

184 MORRIS, supra note 183, at 168.

185 Roosevelt Indorses Recall of Judges, supra note 183, at 5; see generally Ives v. S. Buffalo Ry., 94 N.E. 431 (N.Y. 1911) (holding that the statute violated the Due Process Clause of the Fourteenth Amendment). 
can Convention, which supported President Taft, issued a resolution that stated: "We believe that the guarantees of the Bill of Rights, as incorporated in the Constitution of the United States for the protection of each citizen, even if threatened by a temporary majority, shall be forever preserved." 186 Elihu Root delivered the Keynote Address at the Republican National Convention and said that the recall of judicial decisions was dangerous because "the prohibitions of the Bill of Rights, which protect liberty and insure justice, cannot be enforced except through the determinations of an independent and courageous judiciary." 187 When a bitterly divided Convention chose Taft as its standard bearer, the President issued a statement to The New York Times arguing that the result was a defeat for those who wanted "to weaken the constitutional guarantees of life, liberty, and property, and all other rights declared sacred in the Bill of Rights, by abandoning the principle of absolute independence of the Judiciary essential to the maintenance of those rights." 188

A little reflection, however, reveals a flaw in these arguments that again illustrates the role of the Bill of Rights as a symbol, though this time in support of judicial review rather than federal action. In 1912, only two sections of the initial set of amendments-the Takings Clause and the Due Process Clause-applied to the States. ${ }^{189}$ Since Roosevelt's plan involved the recall of only state judgments, how could this threaten the Bill of Rights? ${ }^{190}$ Perhaps President Taft and his supporters meant that state constitutions protected many rights listed in the first set of amendments and were using the Bill of Rights to represent that idea. A more realistic observation, though, is that the decisions that TR wanted recalled rested on the liberty of contract as interpreted by Lochner $v$. New York. ${ }^{191}$ This controversial doctrine was simply easier to defend when it was characterized as being about the "Bill of Rights." Consequently, the first use of the Bill of Rights to support judicial authority came, ironically enough, in a partisan fight within one of the two political parties.

\section{B. The Road to Barnette}

While the Bill of Rights was in this one instance a handy tool for defending Lochner, when the liberty of contract disintegrated in 1937 that text

186 Taft and Roosevelt Men Go in Same Car, N.Y. Times, June 5, 1912, at 2.

187 Root Address, supra note 178, at 4.

188 President Taft to the Times, N.Y. Times, June 23, 1912, at 1 . None of these citations to the Bill of Rights explicitly refer to the first set of amendments, but in context that is the most likely definition.

189 See Chi., Burlington \& Quincy R.R. Co. v. Chicago, 166 U.S. 226 (1897); see also U.S. Const. amend. XIV, $\S 1$ (requiring states to provide due process).

190 Federal courts would have still been free to protect the Bill of Rights, as Roosevelt was not talking about recalling federal court judgments.

191198 U.S. 45 (1905). Ives v. South Buffalo Railway Co., the case that Roosevelt attacked in his recall speech, was a due process decision. 94 N.E. 431 (N.Y. 1911). 
played a more prominent role in restoring confidence in judicial review. ${ }^{192}$ Consider anew a familiar authority-Footnote Four of United States v. Carolene Products Co. ${ }^{193}$ Footnote Four suggested a new defense of judicial scrutiny that opened with this thought: "There may be narrower scope for operation of the presumption of constitutionality when legislation appears on its face to be within a specific prohibition of the Constitution, such as those of the first ten amendments." 194 In this quote, the Court recognized that the 1791 amendments were a potential resource, but tellingly they did not call that list the Bill of Rights. At this point, the Bill of Rights was still seen as more majoritarian (in aiding the extension of federal authority) than countermajoritarian.

Another irony in the history of the Bill of Rights is that its surge within the Court began with an opinion from Felix Frankfurter, who is not seen as a civil libertarian partly due to his dissent in Barnette. ${ }^{195}$ The first substantial cite to the Bill of Rights in 1940 (and only the second since the 1920s) was in Minersville School District v. Gobitis, ${ }^{196}$ which upheld a mandatory flag salute for kids in public schools. ${ }^{197}$ In Gobitis, Justice Frankfurter wrote: "Centuries

192 See W. Coast Hotel v. Parrish, 300 U.S. 379 (1937) (marking the Court's "switch-intime”). Just two weeks after Roosevelt's 1937 Constitution Day Address, Justice Hugo Black, who would later champion the incorporation of the Bill of Rights, addressed the nation about the revelation that he was once a member of the Ku Klux Klan. See Roger K. Newman, Hugo Black: A Biography 249-50, 255-59 (1994). Justice Black began his radio talk with: "The Constitution is the supreme law of our country. The Bill of Rights is the heart of the Constitution." Id. at 258.

193304 U.S. 144, 152 n.4 (1938). In that same year, the President of the American Bar Association reminded his members that "[a] lawyer drafted the Bill of Rights" and that "[i]t is for lawyers to insist upon the observance of every single guarantee in it." Wertheimer, supra note 8, at 16 (quoting Frank J. Hogan, Lawyers and the Rights of Citizens, 24 A.B.A. J. 615, 616 (1938)). To that end, the ABA created a Special Committee on the Bill of Rights to litigate civil rights cases, and many state and local bar associations followed suit. See id. See generally Brief of the Committee on the Bill of Rights of the American Bar Association, as Friends of the Court, W. Va. State Bd. of Educ. v. Barnette, 319 U.S. 624 (1943). The ABA, like the Court, needed the Bill of Rights to restore a tarnished image in the wake of its dogged defense of the doctrines swept away by the New Deal.

194 United States v. Carolene Prods. Co., 304 U.S. 144, 152 n.4 (1938) (citing Stromberg v. California, 283 U.S. 359, 369-70 (1931); Lovell v. City of Griffin, 303 U.S. 444, 452 (1938)).

195 See Barnette, 319 U.S. at 647 (Frankfurter, J., dissenting) ("I cannot bring my mind to believe that the 'liberty' secured by the Due Process Clause gives this Court authority to deny to the State of West Virginia the attainment of that which we all recognize as a legitimate legislative end, namely, the promotion of good citizenship, by employment of the means here chosen.").

196310 U.S. 586 (1940), overruled by Barnette, 319 U.S. at 642.

197 See id. at 592-94, 599; see also Palko v. Connecticut, 302 U.S. 319, 323, 326 (1937) (containing the only Supreme Court cites to the Bill of Rights during the 1930s), overruled by Benton v. Maryland, 395 U.S. 784 (1969). Unlike the earlier incorporation cases, Palko did refer to the first set of amendments as the "Bill of Rights" even as the Court rejected the extension of the provision at issue-the Self-Incrimination Clause. See id. at 323, 326, 328. And when the Court revisited the total incorporation debate in 1947, all of the Jus- 
of strife over the erection of particular dogmas as exclusive or all-comprehending faiths led to the inclusion of a guarantee for religious freedom in the Bill of Rights." 198 He also said that Pierce v. Society of Sisters ${ }^{199}$ held that "the Bill of Rights bars a state from compelling all children to attend the public schools," even though Pierce said nothing about the Bill of Rights. ${ }^{200}$ Nonetheless, the Court concluded that the "[j]udicial nullification of legislation cannot be justified by attributing to the framers of the Bill of Rights views for which there is no historic warrant."201

While the outcome of Gobitis is contrary to the modern reading of the First Amendment, Justice Frankfurter's dicta marked an important step in the rise of the Bill of Rights. In a sense, the decision sits in an analogous position to Korematsu v. United States, ${ }^{202}$ which upheld an act of racial discrimination but included dicta that ended up helping those who later sought to invalidate discrimination. ${ }^{203}$

\section{A "Fixed Star in Our Constitutional Constellation"}

The decision on the Bill of Rights that everyone reveres is the one that reversed Gobitis. ${ }^{204}$ There are many compelling aspects of Barnette, but the most important for my purposes is that the opinion converted the Bill of Rights into a justification for judicial review in stating that the "very purpose of a Bill of Rights was to withdraw certain subjects from the vicissitudes of political controversy, to place them beyond the reach of majorities and officials and to establish them as legal principles to be applied by the courts." 205 The Court went on to say that "[o]ne's right to life, liberty, and property, to free speech, a free press, freedom of worship and assembly, and other fundamental rights may not be submitted to vote; they depend on the outcome of no elections." 206

tices used "the Bill of Rights" for the first set of amendments. See Adamson v. California, 332 U.S. 46, 51 (1947) (Reed, J.), overruled in part by Malloy v. Hogan, 378 U.S. 1 (1964); id. at 63 (Frankfurter, J., concurring); id. at 68 (Black, J., dissenting); id. at 124 (Murphy, J., dissenting).

198 Gobitis, 310 U.S. at 593.

199268 U.S. 510 (1925).

200 Gobitis, 310 U.S. at 599 (citing Pierce, 268 U.S. 510).

$201 I d$. at 594.

202323 U.S. 214 (1944).

$203 I d$. at 216 ("[A]ll legal restrictions which curtail the civil rights of a single racial group are immediately suspect. That is not to say that all such restrictions are unconstitutional. It is to say that courts must subject them to the most rigid scrutiny.").

204 When then-Attorney General Robert Jackson published The Struggle for Judicial Supremacy in 1941, he explained that the Court was "particularly vigilant in stamping out attempts by local authorities to suppress the free dissemination of ideas, upon which the system of responsible democratic government rests," but then added a footnote with a "compare, however," cite to Gobitis. Robert H. Jackson, The Struggle for Judicial Supremacy: A Study of a Crisis in American Power Politics 284, n.48 (1941).

205 W. Va. State Bd. of Educ. v. Barnette, 319 U.S. 624, 638 (1943).

$206 I d$. 


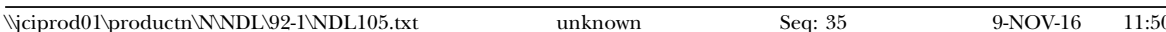

2016]

THE BILL OF RIGHTS AS A TERM OF ART

265

Barnette's rhetoric is so strong that lawyers no longer recognize that a bill of rights meant something different for most of our history. There was a hint that there were other purposes for a bill of rights in Justice Jackson's statement that " $[\mathrm{w}] \mathrm{e}$ must transplant these rights to a soil in which the laissez-faire concept or principle of non-interference has withered at least as to economic affairs, and social advancements are increasingly sought through closer integration of society and through expanded and strengthened governmental controls."207 The missing element of this analysis was that the Bill of Rights played a vital role in validating expanded and strengthened governmental controls, though that obviously would have undercut the point that the Court was trying to make.

Barnette also did its part for the war effort by pitting the Bill of Rights against the Nazis and serving as the judicial complement to Franklin Roosevelt's Bill of Rights Day Address. The Court directly attacked the Führer, noting that the Boy Scouts and the Red Cross objected to the way in which the flag was saluted then-with an outstretched arm-as "being too much like Hitler's."208 Barnette also referred to the "fast failing efforts of our present totalitarian enemies" to stamp out dissent, and conjured the dark image of the concentration camps by stating: "Those who begin coercive elimination of dissent soon find themselves exterminating dissenters."209 The punch line of this section of the opinion was that "[w]e set up government by consent of the governed, and the Bill of Rights denies those in power any legal opportunity to coerce that consent." 210

After World War II, Barnette's description of the Bill of Rights and judicial review supplanted the use of that term to legitimate federal power, ${ }^{211}$ and Justice Jackson's quote is periodically wheeled out to buttress difficult holdings striking down state laws. ${ }^{212}$ The first appearance of this quote came

207 Id. at 640.

$208 I d$. at 627-28 (internal quotation marks omitted).

$209 I d$. at 641.

$210 I d$. I would be remiss if I did not mention Justice Jackson's other well-known comment about the Bill of Rights, which was that the Court should not "convert the constitutional Bill of Rights into a suicide pact.” Terminiello v. Chicago, 337 U.S. 1, 37 (1949) (Jackson, J., dissenting). The Supreme Court has not cited this statement in recent decades, though when the Court did, it did so to uphold an act of Congress. See Am. Commc'ns Ass'n, C.I.O. v. Douds, 339 U.S. 382, 409 (1950) (upholding a clause of the Taft-Hartley Act that targeted alleged communists in unions and quoting the "suicide pact" language (quoting Terminiello, 337 U.S. at 37)).

211 The reason for this transition is beyond the scope of this Article, but the Cold War probably played an important role. When President Harry Truman assumed office, he referred to Franklin Roosevelt's Second Bill of Rights as a key part of his legislative agenda. See Harry S. Truman, Special Message to the Congress Presenting a 21-Point Program for the Reconversion Period, 1945 Pub. Papers 263, 279-80 (Sept. 6, 1945). As the Cold War got underway, however, Truman shifted to using the Bill of Rights to distinguish the United States from the Soviet Union. See infra text accompanying notes 233-36.

212 Barnette's canonical language was also used to condemn decisions insufficiently protective of minority rights. See Emp't Div. v. Smith, 494 U.S. 872, 903 (1990) (O'Connor, J., concurring) (quoting Barnette, 319 U.S. at 638). 
in School District of Abington Township v. Schempp, ${ }^{213}$ which held that a public school could not begin the day with readings from the Bible. ${ }^{214}$ At the conclusion of Schempp, the Court quoted Jackson's line on a bill of rights and said that the quote refuted the claim that "a majority could use the machinery of the State to practice its [religious] beliefs."215 Two decades later, when it invalidated abortion restrictions enacted by Pennsylvania, the Court ended its opinion by citing the same dicta to support that "certain values are more important than the will of a transient majority." ${ }^{216}$ And in Obergefell $v$. Hodges, ${ }^{217}$ the Court quoted most of Jackson's language as representing the "idea of the Constitution" in support of the right to same-sex marriage. ${ }^{218}$

\section{The Right of Privacy}

When Griswold came before the Court in 1965, the Justices again turned to the Bill of Rights to buttress their decision, but this time the Court read the first set of amendments in a more comprehensive way. Justice William O. Douglas's opinion said that an unwritten right of privacy was justified because "specific guarantees in the Bill of Rights have penumbras, formed by emanations from those guarantees that help give them life and substance."219 The Court then cited the First, Third, Fourth, Fifth, and Ninth Amendments as establishing zones of privacy and observed that the enforcement of a ban on contraceptive use would require significant intrusions into those zones. ${ }^{220}$ As Justice Douglas explained more succinctly in his dissent in Poe v. Ullman, ${ }^{221}$ "[c]an there be any doubt that a Bill of Rights that in time of peace bars soldiers from being quartered in a home 'without the consent of the Owner' should also bar the police from investigating the intimacies of the marriage relation?"222

While the Court's discussion of "emanations" and "penumbras" is easy to lampoon, Griswold is the only Supreme Court opinion that actually treats the Bill of Rights as a coherent text. ${ }^{223}$ Still, that effort was more symbolic than real. Much of the Bill of Rights is unrelated to privacy, and a fair observer

213374 U.S. 203 (1963).

214 See id. at 205, 227.

215 Id. at 226.

216 Thornburgh v. Am. Coll. of Obstetricians \& Gynecologists, 476 U.S. 747, 782 (1986), overruled by Planned Parenthood of Se. Pa. v. Casey, 505 U.S. 833 (1992); id. at 782 n.12.

217135 S. Ct. 2584 (2015).

218 See id. at 2605-06 (quoting W. Va. State Bd. of Educ. v. Barnette, 319 U.S. 624, 638 (1943)). The Court substituted "the Constitution" for "the Bill of Rights" in its quotation of Barnette. Id. at 2606.

219 Griswold v. Connecticut, 381 U.S. 479, 484 (1965) (citing Poe v. Ullman, 367 U.S. 497, 516-22 (1961) (Douglas, J., dissenting)).

220 See id. at 484-86.

221367 U.S. 497 (1961).

$222 I d$. at 522 (Douglas, J., dissenting) (quoting U.S. Const. amend. III).

223 Griswold's most overlooked contribution was its statement that the Ninth Amendment was part of the Bill of Rights, which settled the issue of whether the Bill of Rights 
would be hard-pressed to argue that privacy is the most important theme of the first set of amendments. Note, however, how different Griswold's interpretive approach was from the one taken in the liberty of contract cases. Lochner could have ticked off an equally impressive list of clauses in the Second, Third, Fourth, Fifth, and Ninth Amendments that protected property rights and then claimed that these zones supported a constitutional liberty of contract. ${ }^{224}$ Part of the reason this did not happen is that when cases such as Lochner were decided, the idea that the Bill of Rights was a bill of rights was not self-evident, and there was no sense (at least until 1912) that the Bill of Rights had some important meaning for the exercise of judicial review. Griswold came along after the Court had adopted the Bill of Rights as its mascot. ${ }^{225}$

Griswold's other innovation with respect to the Bill of Rights was in its assertion that marriage involved "a right of privacy older than the Bill of Rights,"226 which implied that rights predating the 1791 amendments must be exceptionally important because people recognized them even earlier. Though this language is quoted only in cases that are about marriage, ${ }^{227}$ Justice Kennedy has embraced its theme in more than one opinion to explain why clauses in the 1787 Constitution deserve rigorous enforcement. For instance, in Boumediene v. Bush, ${ }^{228}$ he wrote for the Court that its analysis must begin with two propositions:

First, protection for the privilege of habeas corpus was one of the few safeguards of liberty specified in a Constitution that, at the outset, had no Bill of Rights. In the system conceived by the Framers the writ had a centrality that must inform proper interpretation of the Suspension Clause. ${ }^{229}$

Likewise, in his concurring opinion in the decision invalidating the Line Item Veto Act, Justice Kennedy explained that the framers were so convinced that the "liberty of the person inheres in structure that at first they did not consider a Bill of Rights necessary." 230 In effect, the Bill of Rights was used to

included only the first eight amendments. See Griswold, 381 U.S. at 484. Since 1965, the Court has not defined the Bill of Rights as limited to Amendments I through VIII.

224 The right to possess a gun for self-defense could be characterized as a property right, along with the sanctity of the home from the quartering of troops in peacetime, freedom of homes and personal effects from unreasonable searches and seizures, and the right against a government taking without just compensation.

225 Unlike Barnette's soaring rhetoric, Griswold's discussion of the Bill of Rights on emanations and penumbras did not gain traction in subsequent cases. Since Roe v. Wade, 410 U.S. 113, 129 (1973), no majority opinion has cited that language.

226 Griswold, 381 U.S. at 486.

227 See, e.g., Obergefell v. Hodges, 135 S. Ct. 2584, 2599 (2015) (discussing same-sex marriage (quoting Griswold, 381 U.S. at 486)); Zablocki v. Redhail, 434 U.S. 374, 384 (1978) (invalidating a state statute requiring court approval for a marriage by someone with support obligations to a minor (quoting Griswold, 381 U.S. at 486)).

228553 U.S. 723 (2008).

$229 I d$. at 739.

230 Clinton v. City of New York, 524 U.S. 417, 450 (1998) (Kennedy, J., concurring) (citing The Federalist No. 84, at 513, 515 (Alexander Hamilton) (Clinton Rossiter ed., 
cast a retrospective glow on what the framers proposed, which is the tail wagging the dog from a historical perspective.

In sum, the Justices invoke the Bill of Rights in many forms to discharge their constitutional duties. The first set of amendments, for so long a legal afterthought, is now what Justice Fortas called in 1968 "the great Bill of Rights in our Constitution."231

\section{Conclusion}

On Bill of Rights Day in 1952, the President, the Chief Justice, and many other dignitaries gathered at the National Archives for a special ceremony. ${ }^{232}$ The original Declaration of Independence and the Constitution were being put on display in a new shrine that was meant to preserve these relics for all time. ${ }^{233}$ Joining them was one of the original copies of the Bill of Rights, and in his dedication remarks President Truman stated he was "glad that the Bill of Rights is at last to be exhibited side by side with the Constitution . . . . In my opinion the Bill of Rights is the most important part of the Constitution." 234 This was the case because it is "the only document in the world that protects the citizen against his Government." 235 The Bill of Rights was now assuming a new role as a pillar of American democracy for the Cold War, as Truman went on to discuss how we should respond to the global "threat of totalitarianism and communism." 236

What those in attendance did not know (or just chose to forget) was that the Bill of Rights under glass was not even a bill of rights for the Founders, and was not principally about protecting citizens from their government until the twentieth century. An essential aspect of a canonical text is its susceptibility to many interpretations that allow different schools of thought to embrace at least one of its meanings. ${ }^{237}$ The Bill of Rights possesses the requisite ambiguity because nothing in the text defines the term and because the first set of amendments can easily be understood as representing broad concepts

1961); Gordon S. Wood, The Creation of the American Republic 1776-1787, at 536-43 (1969)); cf. NLRB v. Noel Canning, 134 S. Ct. 2550, 2592 (2014) (Scalia, J., concurring in the judgment) (“ $[\mathrm{T}]$ he Constitution's core, government-structuring provisions are no less critical ... than are the later adopted provisions of the Bill of Rights.").

231 Bloom v. Illinois, 391 U.S. 194, 212 (1968) (Fortas, J., concurring).

232 See, e.g., Constitution and Declaration Unveiled in New Shrine, N.Y. TIMES, Dec. 16, 1952, at 1 .

233 See Harry S. Truman, Address at the National Archives Dedicating the New Shrine for the Declaration of Independence, the Constitution, and the Bill of Rights, 1952-53 Pub. PAPERs 1077 (Dec. 15, 1952).

$234 I d$.

$235 I d$.

236 Id. at 1078.

237 See, e.g., Jack M. Balkin, "Wrong the Day it was Decided": Lochner and Constitutional Historicism, 85 B.U. L. REv. 677, 681 (2005) ("Canonical cases are protean-they can stand for (or be made to stand for) many different things to different theorists, and that is what makes them so useful for the work of theory."). Great literary texts also have this qualityconsider Shakespeare. 
such as the rule of law, judicial review, fundamental rights, or the constitutional right of privacy. At that level of generality, the Bill of Rights can act as a balm to those troubled by extensions of federal authority, as was the case with incorporation, imperialism, the New Deal, and World War II.

In one respect, however, there is a drawback to the devotion that Americans lavish on the Bill of Rights. Flexible as the phrase is, people still understand the text as a product of the eighteenth century. Franklin Roosevelt sought only to supplement that bill of rights with a second one granting positive rights-he did not attempt to redefine the Bill of Rights to include those freedoms. As a result, many of the great constitutional achievements of the past two centuries, especially the Reconstruction Amendments, are excluded from that special club and are not given a place of honor in the National Archives. ${ }^{238}$ There are several obsolete parts of the Constitution that cannot be removed without a formal Article $\mathrm{V}$ amendment, but we are free to enlarge the scope and purpose of the Bill of Rights to reflect contemporary values.

238 Many state bills of rights, for example, include something like the Thirteenth Amendment. See, e.g., Cal. Const. art. I, §6 (stating that slavery is prohibited). One could say that Bolling $v$. Sharpe added the Equal Protection Clause to the Bill of Rights, but lawyers do not typically think of that provision in that way. See Bolling v. Sharpe, 347 U.S. 497 (1954) (holding that public school segregation in the District of Columbia was unconstitutional). 
